\title{
COMMENTS
}

\section{ARE VERDICTS, TOO, LIKE SAUSAGES?: LIFTING THE CLOAK OF JURY SECRECY}

\section{CLIFFORD HOLT RUPRECHT ${ }^{\dagger}$}

If you like laws and sausages, you should never watch either one being made."

This Comment argues that jury deliberations should be transcribed as part of the ordinary trial record and be subject to a limited judicial review. Such limited review is the proper way to mediate the conflict between two important political principles. On the one hand, there is a pragmatic need to accept some degree of imperfection in our political institutions and to permit such imperfection to pass unexamined-hence the appeal of Bismarck's wry comment. ${ }^{2}$ On the other hand, meaningful self-government requires accountability of the government to the governed. Hence, the principle behind Bismarck's remark should be deeply troubling to any proponent of the democratic ideal, for that principle demands a degree of popular acquiescence to the conduct of government in secret, which is a step in the direction of government without the consent of the

† B.A. 1986, Williams College; Ph.D. 1995, University of Chicago; J.D. Candidate 1998, University of Pennsylvania. I wish to acknowledge the support of the staff of the Law Review. Their gracious assistance and tireless industry have saved me many embarrassments in the publication of this piece. Most importantly, I am so grateful to Patty Ruprecht, for her good humor, her patience with me, and her company. To her I have dedicated all-and so this little work, too.

${ }^{1}$ This quotation is widely attributed to Otto von Bismarck, but the attribution is unverified. SeeRESPECTFULly QUOTED 190 (Suzy Platt ed., 1992).

${ }^{2}$ This pragmatic acceptance of imperfection is an important feature of our judicial institutions, as the harmless-error doctrine shows: “[T]he Constitution entitles a criminal defendant to a fair trial, not a perfect one." Delaware v. Van Arsdall, 475 U.S. 673,681 (1986). In fact, "there can be no such thing as an error-free, perfect trial"; hence, "the Constitution does not guarantee such a trial." United States v. Hasting, 461 U.S. 499, 508-09 (1983). The Supreme Court has applied this principle equally in the civil context, stating that a civil litigant, too, is only entitled to a fair, not a perfect, trial, and commenting that "[i]t seems doubtful that our judicial system would have the resources to provide litigants with perfect trials." McDonough Power Equip., Inc. v. Greenwood, 464 U.S. 548, 553 (1984). 


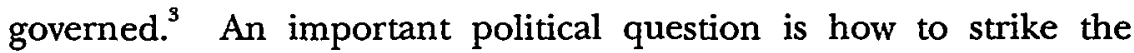
proper balance between the pragmatic refusal to demand perfection of our political institutions and the countervailing demand of accountability of those institutions to the governed. ${ }^{4}$ With respect to jury deliberations, this means striking the proper balance between the need for jury secrecy and the public's demand to supervise the jury's activity.

To insist on the near-absolute secrecy of jury deliberations, as courts and commentators routinely do, is to ignore the need for balance, favoring pragmatic secrecy over principled openness. ${ }^{5}$ Where government activity must be conducted in secret, so that the actors are not accountable directly to the public, those actors should be overseen by, and accountable to, other government representatives. ${ }^{6}$ The jury, however, is essentially accountable to no one. Jurors

${ }^{3}$ As Justice Stevens has noted: "A popular Government, without popular information, or the means of acquiring it, is but a Prologue to a Farce or a Tragedy; or, perhaps both. Knowledge will forever govern ignorance: And a people who mean to be their own Governors, must arm themselves with the power which knowledge gives." Houchins v. KQED, Inc., 438 U.S. 1, 31-32 (1978) (Stevens, J., dissenting) (quoting Letter from James Madison to W.T. Barry (Aug. 22, 1822), in 9 THE WRITINGS OF JAMES MADISON, 1819-1836, at 103, 103 (Gaillard Hunt ed., 1910)).

What one author has said of this balance with regard to foreign policy is true of public policy generally:

Secrecy is both necessary and antithetical to the foreign policy processes of democratic government: necessary, because foreign affairs may involve sensitive ... relationships that cannot withstand the often destructive inquiry of a divisive political arena; yet antithetical, because [that policy turns on] values best expounded through robust civic discussion, which secrecy inhibits and impairs.

Note, Keeping Secrets: Congress, the Courts, and National Security Information, 103 HARV. L. REV. 906, 906 (1990).

${ }^{5}$ I do not mean to suggest that secrecy is necessarily unprincipled. One commentator, for example, explains that:

[S]ome tension exists between the openness and responsiveness that American society demands of most government processes and the privacy and independence that it accords to the deliberations of the jury. But this tension is no fortuity: the American jury was probably designed partly to resist the very impulses of majoritarianism that press for the exposure of deliberations in any given case.

Note, Public Disclosures of Jury Deliberations, 96 HARV. L. REV. 886, 894 (1983) (footnote omitted). Nonetheless, the justifications offered for the secrecy of jury deliberations are often based on pragmatic considerations rather than principles. See id. at 891-92, 897 (justifying secrecy on the pragmatic grounds of finality, authoritativeness, and buttressing public faith in the verdicts rendered).

'Justice Stevens emphasized that:

[T] here are unquestionably occasions when governmental activity may properly be carried on in complete secrecy... . [S] Jome functions of government- 
decide whether the coercive power of the state should be invoked to deprive a party of liberty, property, or even life. Such governmental decisionmakers should be accountable to the people. ${ }^{7}$ Jury secrecy, as currently practiced, does not properly balance the pragmatic tolerance of imperfection and the public's demand for accountability.

While jury secrecy as currently practiced is too extreme, the remedy to this is not a general right of access to jury deliberations. The secrecy of the jury is a treasured feature of our common-law heritage, and a proposal to infringe in any way on that secrecy should expect strong resistance. Any claim for a general right of access to jury deliberations ignores the valid insight that some degree of jury secrecy is probably necessary to the fair and efficient administration of justice.

Failure to acknowledge the legitimacy of both of these opposing claims impairs critical reflection on the institution of the jury. To illustrate this point, the Comment analyzes the debate over CBS's recent network-television broadcast of jury deliberations. ${ }^{9}$ The controversy nicely demonstrates the need for a critical attitude more tolerant of compromise and more amenable to the proposal ad-

essential to the protection of the public and indeed our country's vital interests-necessarily require a large measure of secrecy, subject to appropriate legislative oversight. In such situations the reasons for withholding information from the public are both apparent and legitimate.

Houchins, 438 U.S. at 3435 (Stevens, J., dissenting) (emphasis added) (footnote omitted).

${ }^{7}$ See Abraham S. Goldstein, Jury Secrecy and the Media: The Problem of Postverdict Interviews, 1993 U. ILI. L. REV. 295, 313 (noting the view that "jurors are public servants; exposing them to public scrutiny would enhance their accountability to the community they represent"); infra Part III.A (arguing that jury secrecy as currently practiced unnecessarily undermines "the public's interest in supervised government processes").

The First Circuit has recognized that the role of jurors as government decisionmakers ("citizen soldiers") disfavors juror anonymity: "[T] he prospect of criminal justice being routinely meted out by unknown persons does not comport with democratic values of accountability and openness." In re Globe Newspaper Co., 920 F.2d 88, 98 (1st Cir. 1990).

${ }^{B}$ See Abraham Abramovsky, Cameras in the Jury Room: Education or Danger?, N.Y. L.J., Apr. 8, 1996, at 3 ("Arguing against the filming of jury deliberations ... is a centuriesold tradition of jury privacy that is a treasured part of the jurisprudence of federal and state courts.").

${ }^{9}$ See CBS Reports: Enter the Jury Room (CBS television broadcast, Apr. 16, 1997) [hereinafter CBS Reports]. Because the transcript is readily available from Burrelle's Transcripts, Livingston, NJ, references to CBS Reports will be followed, where appropriate, by a page reference to the transcript. 
vanced here: to supervise the jury's decisionmaking more closely than it traditionally has been.

Consequently, the structure of the Comment is as follows. Part I explains the background of the CBS project and the procedure followed in taping the jury deliberations for network broadcast. Part II surveys arguments for and against televising jury deliberations. On the basis of Parts I and II, Part III shows that neither the near-absolute secrecy that jury deliberations currently enjoy nor the network broadcast of jury deliberations is desirable. Part III then argues that a mediating alternative is more appropriate: Transcribing jury deliberations for judicial review satisfies the demand for public accountability underlying the efforts to televise jury deliberations, while protecting the jury from some of the more unwanted intrusions that television broadcast entails. Part IV examines the legality of recording jury deliberations for judicial review. While no constitutional impediment to such a procedure exists, there are certain statutes and rules that would bar the procedure; Part IV therefore recommends amendments to those statutes and rules. Part $\mathrm{V}$ then offers some proposals as to the nature and scope of judicial review of a jurydeliberation transcript.

\section{THE CBS PROJECT: BACKGROUND AND PROCEDURE}

In April 1997, the CBS television network aired a documentary consisting primarily of actual footage of criminal-jury deliberations. ${ }^{10}$ This Part describes the historical background of the project and the procedure followed in taping jury deliberations for network broadcast.

The CBS project is simply the latest in a series of public inquiries into juries' secret deliberations. Post-verdict interviews of jurors by the media are quite common and have been the subject of significant legal commentary. ${ }^{11}$ There have also been other forms of media intrusion into, as well as nonmedia public inspection of, jury deliberations.

Possibly the most infamous inquiry into jury deliberations was

${ }^{10}$ See id. The producer of CBS Reports has very recently published a useful summary of the project and his assessment of what the project reveals about the need for jury reform. See David Schneider, Jury Deliberations and the Need for Jury Reform: An Outsider's View, JUDGES' J., Fall 1997, at 23.

"See generally, e.g., Goldstein, supra note 7 (exploring the problems with postverdict interviews); Note, supra note 5 (same). 
conducted not by the media but by social-science researchers. Members of the Chicago Jury Project tape-recorded jury deliberations in the Federal District Court in Wichita, Kansas. ${ }^{12}$ The revelation of this breach of jury secrecy and the ensuing scandal ${ }^{13}$ prompted Congress to enact an absolute ban on any recording of jury deliberations in the federal courts. ${ }^{14}$ Despite the scandal, the intrusion produced a study of the American jury that remains preeminently authoritative. ${ }^{15}$

${ }^{12}$ See H.R. REP. No. 84-2807, at 1-2 (1956), reprinted in 1956 U.S.C.C.A.N. 4149, 4149. While the taping took place with the permission of the court, the jurors neither consented to nor knew of the recording. See id. at 2, reprinted in 1956 U.S.C.C.A.N. $4149,4149$.

${ }^{13}$ The participants were called before the Senate Subcommittee to Investigate the Administration of the Internal Security Act. The ostensible purpose of the hearing was "to permit assessment of the impact of this activity upon the integrity of the jury system, as a basis for decision respecting what legislation may be necessary to protect the jury system." Recording of Jury Deliberations: Hearings Before the Subcomm. to Investigate the Admin. of the Internal Sec. Act and Other Internal Sec. Laws of the Senate Comm. on the Judiciary, 84th Cong. 1 (1955) [hereinafter Hearings] (statement of Sen. James O. Eastland, Chairman of the Subcommittee). The proceedings as a whole, however, had the inquisitorial feel of the hunts for "subversives" common at the time. See id. at 23-31 (questioning Edward H. Levi, Dean of the University of Chicago Law School, as to knowledge of suspected Communists, membership in suspect organizations, and public statements critical of the House Un-American Activities Committee); id. at 4657 (questioning Harry Kalven, Jr., as to his sympathy for the Rosenbergs); id. at 84-103 (questioning Mr. Kalven as to agreement with statements of Communists, and as to his public statements on the Oppenheimer affair, membership in suspect organizations, and participation in suspect rallies). In this light, the Chairman's expression of fear that "there may be some criticism of the subcommittee in this instance for venturing into a matter which does not appear to involve subversives or subversion," id. at 1 , appears at best unfounded and, at worst, disingenuous.

${ }^{14}$ See Act of Aug. 2, 1956, Pub. L. No. 84-919, 70 Stat. 935 (1956) (codified as amended at 18 U.S.C. $\$ 1508$ (1994)). Section 1508 provides:

Whoever knowingly and willfully, by any means or device whatsoever-

(a) records or attempts to record, the proceedings of any grand or petit jury in any court of the United States while such jury is deliberating or voting...

$\cdots$

shall be fined under this title or imprisoned not more than one year, or both.

18 U.S.C. $§ 1508$ (a).

${ }^{15}$ See Harry Kalven, JR. \& HaNs Zeisel, The AMERican JuRY (1966) (detailing the findings of a broad, social-science study of American juries).

Ironically, the continued preeminence of that study is surely due in part to the legislative action that was meant to impugn the authors. Since the enactment of 18 U.S.C. $\$ 1508$, social-science research has made do without entering the actual jury room. Researchers have probed the jury's deliberative process by studying various substitutes for actual juries. The most popular substitutes are "mock juries" (panels selected just as actual juries might be selected, but deciding a fictitious case, often under conditions not identical to actual trial conditions) and "shadow juries" (panels that observe a real trial or hear the evidence actually adduced at trial and decide the 
While the Chicago Jury Project may be the most striking example of inspection of jury deliberations, media inquiries into the jury's secret deliberations are more common. Typically, the media probe the jury's deliberations through post-verdict interviews, but other techniques also have been tried. Television producers have reassembled actual juries to reconstruct their deliberations before the camera. $^{16}$ And on one prior occasion, a jury deliberation has been broadcast on television. PBS filmed the deliberation of a jury in a Wisconsin criminal trial for a documentary that was aired in $1986 .{ }^{17}$ Never before, however, has a commercial broadcast network televised the deliberations of either a criminal or a civil jury. ${ }^{18}$

As it turned out, CBS was able to film criminal juries only, because the project underwent significant changes between planning and execution. CBS proposed to record the deliberations of criminal juries in Arizona and of civil juries in Maine. The high courts of each state granted permission for the filming. ${ }^{19}$ The recording of civil

case, for the purpose of observing the deliberation and comparing the result with that of the actual jury). The theoretical value of such ersatz juries as objects of study is contested. See generally JERALD GREENBERG \& ROBERT FOLGER, CONTROVERSIAL ISSUES IN SOCIAL RESEARCH METHODS 61-78 (1988) (exploring concerns about the artificiality and limited generalizability of "laboratory experiments" in the social sciences). This partially explains the special reverence accorded The American Jury. As the authors explain after summarizing the scandal regarding the Wichita jury:

None of the Wichita data is included in this book, nor will it be included in future books. We note the episode here simply to make clear to that man who would say, "That's all very interesting, professors, but did you ever hear a real jury deliberate?" that the answer is Yes, and to point out that one of the distinctions of the jury study is that it is a research project that has a Purple Heart.

KALVEN \& ZEISEL, supra, at vii.

${ }^{16}$ See United States v. Rees, 193 F. Supp. 861, $861-62$ (D. Md. 1961) (describing a videotaped reenactment of jury deliberations by nine jurors that was broadcast on a local television station).

${ }^{17}$ See Frontline: Inside the Jury Room (PBS television broadcast, Apr. 8, 1986) (documenting jury deliberations in the case of a sympathetic defendant charged with unlawful possession of a firearm, which resulted in an acquittal despite the defendant's concession at trial of his guilt on all elements of the crime charged).

${ }^{18}$ See Jason Wolfe, TV Justice Documentary Won't Include Maine Jurors, PORTLAND PREss HeRALD, May 18, 1996, at 1A, available in LEXIS, News Library, Portps File (noting that the CBS project is "unprecedented in commercial television").

${ }^{19}$ In Maine, the high court granted permission through a formal, published order. See Administrative Order, No. SJC-228, 1996 Me. LEXIS 32 (Feb. 5, 1996) [hereinafter Administrative Order] (authorizing CBS to record the deliberations subject to certain conditions). The Maine court's order engendered an immediate effort, ultimately unsuccessful, to bar the recording through emergency legislative action. See Wolfe, supra note 18, at $1 \mathrm{~A}$ (reporting that the dissent to the administrative order "prompted 
juries in Maine, however, ultimately fell through. Producers identified seventeen docket entries as candidates for taping but were only able to find one case in which both parties would consent to having the jury filmed. That case, an automobile-accident negligence claim, settled shortly before trial. The producers hurriedly tried to find another case to film, but were unsuccessful and gave up in the face of impending production deadlines. ${ }^{20}$

CBS has successfully recorded four criminal trials and deliberations in Arizona. ${ }^{21}$ The production protocol followed in Arizona was essentially the same as that submitted to the Maine Supreme Judicial Court, $^{22}$ which incorporated the protocol by reference in the court's administrative order. ${ }^{23}$

a state lawmaker to propose emergency legislation to outlaw electronic taping of a jury session to protect the secret jury process").

There was high drama in this legislative phase. The state House of Representatives endorsed the bill 131-11, but in the waning days of the legislative session, the Senate rejected the bill by one vote. See Senate Rejects Bill to Block Jury Taping, PORTLAND PRESS HERALD, Mar. 31, 1996, at 7B, available in LEXIS, News Library, Portps File. The Senate's refusal to appoint a conference committee spelled the project's end. See Maine Won't Ban Cameras from Jury Room, PORTLAND PrEss HERALD, Apr. 3, 1996, at 10A, available in LEXIS, News Library, Portps File.

News of the project also inspired scholarly criticism. See Abramovsky, supra note 8 (arguing that the Maine order was wrongly issued and that other courts should not follow Maine's lead). The public character of the Maine court's grant of permission certainly contributed to the attention that the issue received in Maine, and the turmoil that ensued "likely contributed to the difficulties in finding a case" there. Wolfe, supra note 18 (citing an attorney closely involved with the project).

In Arizona, the procedure was much more informal. A CBS producer who had a prior acquaintance with Judge Michael Dann of the Maricopa County Superior Court approached Judge Dann about the prospect of taping in Arizona. Judge Dann then discussed the issue with Chief Justice Stanley Feldman of the Arizona Supreme Court. After clearing the matter with the rest of the high court, the Chief Justice gave CBS verbal permission to pursue the project, subject to the consent of the trial court, the parties, counsel, and the jurors. See Telephone Interview with Hon. Michael Dann, Judge of the Superior Court of Maricopa County (Nov. 13, 1996). In light of the trouble in Maine, the Arizona procedure was certainly the more effective course.

${ }^{20}$ See Wolfe, supra note 18.

See Telephone Interview with David Schneider, Senior Producer, CBS Reports, CBS, Inc. (Nov. 4, 1996).

${ }^{22}$ See id.

${ }^{23}$ See CBS Reports: Inside the Jury Room-Production Protocol, Jan. 15, 1996, Attachment to Administrative Order, supra note 19 , at $* 6-* 15$ [hereinafter CBS Production Protocol]. The administrative order incorporates the production protocol by express reference: "The project . . . is to be conducted in accordance with the production protocol attached hereto." Administrative Order, supra note 19, at *1. 
The most relevant features of the procedure followed in the CBS project are that consent not only of the court, but of all parties ${ }^{24}$ and of the individual jurors ${ }^{25}$ was obtained, ${ }^{26}$ and that the parties waived the filming of the deliberations as a basis for appeal. ${ }^{27}$ Under these conditions, highlights from the four Arizona criminal trials and deliberations were aired as part of CBS's documentary. ${ }^{28}$

\section{Debate ON THE CBS PROJECT: MAINTAINING ABSOlUte JuRY SECRECY VERSUS TELEVISING JURY DELIBERATIONS}

Debate surrounding the CBS project illustrates the problems that arise from the failure to acknowledge the need to compromise between two competing values: (1) accountability and (2) pragmatic tolerance of imperfection in our political institutions. The CBS project and other public inquiries into jury deliberations are certainly instances of sensationalism in the media. These inquiries, however, also indicate an understandable desire for a more accountable jury system. $^{29}$

${ }^{24} \mathrm{See}$ CBS Production Protocol, supra note 23, at *9 (suggesting that the court may obtain consent of the parties but requesting involvement of CBS in the process).

${ }^{25}$ See id. at $* 9-* 10$ (recommending that consent be obtained prior to impaneling the jury by prescreening the venire and excusing nonconsenting venirepersons to serve on other juries). filming).

${ }^{26}$ See CBS Reports, supra note 9 , at 5 (noting the consent of all involved in the

${ }^{27}$ See CBS Production Protocol, supra note 23 , at $* 9$ (detailing the consents and waivers required and the procedures to be followed).

${ }^{28}$ See Telephone Interview with David Schneider, supra note 21. CBS filmed four trials but only three cases. One of the four trials filmed was a retrial after a hung jury resulted in a mistrial. The three cases were:

(1) Arizona v. Lopez, involving a charge of armed robbery, with the jury asked to resolve conflicting testimony on whether the defendant in fact drew a gun while stealing beer from a store, see CBS Reports, supra note 9, at 5-32;

(2) Arizona v. Solano, involving charges of drug possession, trafficking, and conspiracy, with the key jury issue being the defendant's knowledge that there were 128 pounds of marijuana and one kilogram of cocaine in the suitcases she was carrying upon arrest at the airport, see id. at 32-50; this case had to be retried due to a hung jury, and CBS filmed the retrial as well, seeid. at 50-59; and

(3) Arizona $v$. York, involving a charge of aggravated assault, with the jury asked to decide whether the defendant acted recklessly or reasonably in firing a shotgun at and wounding a man the defendant thought had a gun, see id. at 59-70; this was the defendant's second of three trials and was the only trial of the defendant that CBS filmed; the first two trials resulted in hung juries, and the third trial resulted in an acquittal, see id. at 70.

${ }^{2}$ While a desire for ratings surely played a key role in CBS's business decision to air the documentary, the network has suggested that the editorial motivation for the 
There is a similar mixture of illegitimate and legitimate motivations in the opposition to the CBS project. On the one hand, opposition arises from an illegitimate, purely reactionary, conservatism that resists change merely because it is change. ${ }^{30}$ On the other hand, opposition also arises out of a legitimate concern for the preservation of the dignity of our judicial institutions and the neutrality of the jury.

This Part of the Comment endeavors to demonstrate three points. First, detractors have attacked the CBS project merely because it involves a breach of jury secrecy. This criticism manifests a knee-jerk conservatism and is not an adequate criticism of the project. ${ }^{32}$ Second, CBS's critics make a more persuasive point when their criticism is directed at the project's special character as a televised breach of jury secrecy. Nonetheless, this criticism is not tempered by any acknowledgment of the legitimate desire to inspect the jury's activity. This weakens the criticism significantly. ${ }^{33}$ Third, a more valid criticism of the CBS project, one that recognizes the legitimacy of the concern for accountability that animates the project, is that this media inspection of the jury's deliberations cannot be supported by any of the traditional justifications of press access to government activity. ${ }^{34}$

Overall, this Part of the Comment seeks to establish that there is a legitimate need to observe more closely the jury's deliberations, and

project is to provide "a remarkable opportunity to consider the question: Does the road to justice lead through the jury room?" CBS Reports, supra note 9, at 3.

Chief Justice Feldman of the Arizona Supreme Court noted that it was "a difficult decision" to permit CBS to "intrud[e] into the sanctity of the jury room," and acknowledges a "fear that we might, by observing, change the ... process, change the result." Id. at 4. Nonetheless, Chief Justice Feldman decided to grant CBS permission as a way of rendering the jury more accountable: "So I thought to myself that, "Well, if you think this is ... such a good system for the people of the United States, well, the people of the United States ought to have ... a look at it and judge for themselves." Id. at 5.

Both CBS and Chief Justice Feldman sought to render the jury system accountable to the public, not to render the juries themselves accountable for their verdicts. The lack of accountability of the jury for its decisions is an abiding source of criticism of the institution. See Hearings, supra note 13, at 73 (memorandum submitted by Harry Kalven, Jr.) (noting the argument that juries make worse factfinders and policy deciders than judges because jurors 'don't have to live with their decisions, and haven't got their reputations and professional standings at stake").

\footnotetext{
See infra Part II.A.

s1 See infra Part II.B.

${ }^{52}$ See infra Part II.A.

ss See infra Part II.B.

${ }^{34}$ See infra Part II.C.
} 
that failure to acknowledge this need leads to two problems. At the social level, failure to acknowledge the need to supervise the jury invites attempts like the CBS project to address the need through undesirable means. At the analytical level, failure to acknowledge this need (for instance, by insisting that jury secrecy remain as absolute as it has been traditionally) impoverishes critical reflection on problems involving the jury (like the CBS project).

\section{A. Traditional Justifications of Jury Secrecy Do Not Justify Opposition to the CBS Project}

Some critics have opposed the CBS project simply because it runs afoul of a long tradition of secret jury deliberations. ${ }^{35}$ These arguments ignore the fact that the CBS project was carefully tailored to avoid infringing upon the interests traditionally protected by jury secrecy. Consequently, the traditional arguments for jury secrecy are insufficient to justify opposition to the CBS project, and accordingly, criticizing the project merely because it involves a breach of secrecy is not persuasive.

Three claims typically are offered to justify the near-absolute jury secrecy that exists in American courts: Secrecy encourages frank discussion among jurors; ${ }^{36}$ secrecy promotes the stability of verdicts; ${ }^{37}$ and secrecy respects the privacy of jurors. ${ }^{38}$ None of these justifications warrants banning the CBS project.

\section{Frankness of Discussion}

The Supreme Court recognized long ago that "[f]reedom of debate might be stifled and independence of thought checked if jurors were made to feel that their arguments and ballots were to be freely published to the world. ${ }^{39}$ Other courts have employed similar logic, reasoning that "the secrecy of jury deliberations fosters free, open, and candid debate in reaching a decision." ${ }^{40}$ Consequently, there is

${ }^{\text {ss }}$ See Abramovsky, supra note 8 ("Arguing against the filming of jury deliberations ... is a centuries-old tradition of jury privacy that is a treasured part of the jurisprudence of federal and state courts. ${ }^{n}$ ).

${ }^{36}$ See infra Part II.A.1.

${ }^{37}$ See infra Part II.A.2.

ss See infra Part II.A.3.

${ }^{39}$ Clark v. United States, 289 U.S. 1, 13 (1933).

10 In re Globe Newspaper Co., 920 F.2d 88, 94 (1st Cir. 1990). Importantly, despite the long pedigree behind this principle, it has no clear empirical support. See infra note 117 and accompanying text. 
no general public right of access to jury deliberations. ${ }^{41}$ But the questions remain: Whose interest do jury secrecy and freedom of debate promote? And more importantly, whose protected interest does the CBS project infringe?

Arguably, the jurors, the parties, and the public all have an interest in ensuring that jury debates be free and open. The jurors have a participatory interest in the proceeding. ${ }^{42}$ They exercise a civic duty in sitting on a jury and have an interest analogous to the political voters' interest. ${ }^{43}$ Therefore, a juror has a cognizable interest in voting her conscience in a matter of grave public import unobstructed by concern for prying eyes on her vote.

The parties have an interest in ensuring that the jurors debate as openly as possible: "The jury system is predicated on the insight that people see and evaluate things differently. It is one function of the jury to bring these divergent perceptions and evaluations to the trial process." ${ }^{\prime 4}$ Due to the jurors' divergent perceptions and evaluations, each party presumably has interests that some jurors will represent more vigorously than others. ${ }^{45}$ Each party, therefore, has an interest in encouraging zealous advocacy for that party before the other jurors. If a juror does not feel free to advocate openly for one party's position, that party clearly suffers.

Finally, the public has an interest in the fairness of the judicial proceeding. ${ }^{46}$ In large part, this fairness is a function of each party's

${ }^{11}$ See Globe Newspaper, 920 F.2d at 94 ("There is ... clearly no public right of access to the jurors' deliberations themselves.").

12 See Mary A. Lynch, The Application of Equal Protection to Prospective Jurors with Disabilities: Will Batson Cover Disability-Based Strikes?, 57 ALB. L. REV. 289, 297 n.53 (1993) (noting that "jury service is . . a significant form of participation in our democratic and judicial systems").

4s See id. at 297-98 (noting that "with the exception of voting, for most citizens the honor and privilege of jury duty is their most significant opportunity to participate in the democratic process" (quoting Powers v. Ohio, 499 U.S. 400, 407 (1991))); $c f$. Powers, 499 U.S. at 408 (drawing an analogy between jury service and elective franchise, and noting that a state may no more invidiously discriminate against the one privilege than it may against the other).

"Hans Zeisel, ... And Then There Were None: The Diminution of the Federal Jury, $38 \mathrm{U}$. CHI. L. REV. 710, 715 (1971).

${ }^{45}$ Cf. Nancy S. Marder, Note, Gender Dynamics and Jury Deliberations, 96 YALE L.J. 593, 599-600 (1987) (noting that under-participation by women jurors endangers the accuracy and fairness of verdicts because men and women bring differing perspectives to jury deliberations).

${ }^{45}$ See Press-Enterprise Co. v. Superior Court, 464 U.S. 501, 509 (1984) (acknowledging the "concerns of ... the community in knowing that offenders are being brought to account for their criminal conduct by jurors fairly and openly 
position receiving a hearing before the jury (both at trial and in the jury room). ${ }^{47}$ Therefore, the public's interest is quite similar to the parties' interest in free deliberation by the jurors.

Assuming that all the constituencies previously mentioned have an interest in preserving freedom of debate among jurors, are these interests trammeled when deliberations are televised with the consent of the jurors, the parties, and the court? Probably not.

Significantly, the jurors consent to being filmed. One may question whether that consent is fully informed, given that most of the jurors will not have known, at the time of consenting, what the deliberations will involve, or how they will feel about expressing themselves freely before the camera. By the same token, however, jurors know the general nature of the risk they have assumed: that there may be sensitive matters that arise for discussion, and that the discussion will be televised. It seems unnecessary to require that the juror foresee precisely the scruples she may feel during deliberation in order for her consent to be deemed informed. The jurors are fully cognizant of the nature of the interest implicated when they consent to be filmed, even if they are ignorant of the degree to which, or the exact manner in which, that interest will be implicated. Consequently, it seems unduly paternalistic to substitute the critic's judgment for the jurors' own in determining how best to promote their interests.

Just as the CBS project does not improperly infringe on the jurors' interests, it does not improperly infringe on the parties' interests either. The parties also consent to having their cause adjudicated by a jury that consents to be filmed. It may be true that jurors may not deliberate as freely as they should when faced with the reality of doing so on camera. Hence, the parties' right to a fair adjudication may be

selected"); $c f$. Richmond Newspapers, Inc. v. Virginia, 448 U.S. 555, 571 (1980) (plurality opinion) (" $[E]$ specially in the administration of criminal justice, the means used to achieve justice must have the support derived from public acceptance of both the process and its results."); Globe Newspaper, 920 F.2d at 93-94 ("[O]pen justice serves... [to] ensur[e] public confidence in a trial's results through the appearance of fairness ....").

${ }^{47}$ For example, the Supreme Court has held it to be a fundamental error for a court to give the jury instructions or to respond to jury queries when one party is not present, whether in a civil case, see Fillippon v. Albion Vein Slate Co., 250 U.S. 76, 81 (1919) (noting that the parties in a civil case are entitled "to be present in person or by counsel at all proceedings from the time the jury is impaneled until it is discharged after rendering the verdict"), or in a criminal case, see Rogers v. United States, 422 U.S. 35, 38 (1975) (applying the Fillippon standard to criminal cases). 
compromised by the filming. ${ }^{48}$ The parties, however, have even less right to complain than the jurors. The risk of a stifled deliberation is precisely the risk the parties assume when they consent to a televised jury-and they do so with the benefit of counsel. In no sense is the parties' consent uninformed. The parties willingly assume the risk of a restricted deliberation, presumably in exchange for some perceived gain. ${ }^{49}$ Again, the critics' judgment of the parties' best interests should not be substituted for the parties' own judgment, particularly as the matter concerns the parties far more significantly than it does any critic.

But if the jury deliberates improperly due to the distorting influence of the television camera, is not the public's interest in the fairness and accuracy of the adjudication compromised? Arguably not. The parties' consent does much to legitimate the proceeding. For instance, parties may consent to having their cause tried by a lone judge rather than by a jury, ${ }^{50}$ or they may submit to the binding decision of a single arbitrator, ${ }^{51}$ even though we presume that the judgment of twelve is sounder than the judgment of one. ${ }^{52}$ The legitimating force of the parties' voluntary choice of a deliberative mechanism presumably offsets any delegitimization that might follow from the diminution of the soundness of the judgment.

It is possible that in certain circumstances a consensual modification of the judicial process will not be honored by a court, on the grounds that the public interest has been ill-served by the public's proxy. For example, a plea bargain agreed upon by the defendant and the prosecution may be rejected by the court. ${ }^{53}$ In these instances, the public's interest in the prosecution going forward is held

${ }^{13}$ See Abramovsky, supra note 8 (discussing the dangers of videotaped deliberations).

49e Wolfe, supra note 18 (noting that one attorney who consented to having his client's case videotaped by CBS did so "as a tactical move" and thought that "jurors, knowing they were being filmed, would pay closer attention to his defense").

${ }^{50}$ See generally 75B AM. JUR. 2D Trial $\$ 1956$ (1992) (explaining the right of parties to waive jury participation).

${ }^{31}$ See, e.g., Federal Arbitration Act, 9 U.S.C. \$§ 1-16 (1994) (giving district courts broad powers to enforce arbitration agreements).

${ }^{52}$ See Sioux City \& Pac. R.R. Co. v. Stout, 84 U.S. 657, 664 (1873) ("It is assumed that twelve men know more of the common affairs of life than does one man, that they can draw wiser and safer conclusions from admitted facts thus occurring than can a single judge.").

${ }_{53}$ See, e.g., FED. R. CRIM. P. 11(e)(2) (permitting a federal court to reject a plea agreement); FED. R. CRIM. P. 11(f) (requiring a federal court to reject a voluntary plea lacking any factual basis). 
to have been inadequately protected by the public's delegate, the prosecutor. $^{54}$ More precisely, one delegated guardian of the public interest, the judge, has exercised her superior authority to veto an inferior delegate's (the prosecutor's) estimate of what the public interest demands.

The situation is quite different when the parties consent to the verdict of a filmed jury. In that event, the consent of the parties combined with the consent of the public's delegate (the judge in a civil case) or delegates (the judge and the prosecutor in a criminal case) legitimates the entire undertaking. Under these circumstances, it is difficult to argue that the public interest is insufficiently protected and that the consent of all involved must not only be disregarded but must also be disrespected.

\section{Stability of Verdicts}

Courts have long recognized that the public interest in the stability of verdicts, once rendered, counsels against receiving juror testimony to impeach the jurors' own verdict. This is true despite the litigants' strong claim of a right to a trial by a fair and competent jury.

In $M c D o n a l d ~ v$. Pless, the Supreme Court held:

[T] he argument in favor of receiving such evidence [juror testimony] is not only very strong, but unanswerable-when looked at solely from the standpoint of the private party who has been wronged by [juror] misconduct. The argument, however has not been sufficiently convincing to induce legislatures generally to repeal or to modify the rule [barring such evidence]. For, while it may often exclude the only possible evidence of misconduct, a change in the rule "would open the door to the most pernicious arts and tampering with jurors." "The practice would be replete with dangerous consequences." "It would lead to the grossest fraud and abuse" and "no verdict would be safe..$^{55}$

Accordingly, the Court held that juror testimony revealing a quotient verdict could not be received to disturb the improperly rendered verdict, despite the fact that several jurors disagreed with the verdict and assented only because they felt bound by a prior agreement. ${ }^{56}$

54 See Abraham S. Goldstein, Converging Criminal Justice Systems: Guilty Pleas and the Public Interest, 49 SMU L. REV. 567, 571-72 (1996) (noting that a judge should reject a guilty plea when it is not in the public interest and describing the "consensus" on the criteria a judge should apply in rejecting a plea).

${ }^{55} 238$ U.S. 264, 268 (1915) (citations omitted).

${ }^{56}$ See id. at 269 (" $[1] \mathrm{t}$ is safe to say that there is nothing in the nature of the present case warranting a departure from what is unquestionably the general rule, that the 
- The Court recognized that in disallowing such juror testimony, it "chooses the lesser of two evils" because it "must choose between [not] redressing the injury of the private litigant and inflicting the public injury which would result if jurors were permitted to testify as to what had happened in the jury room. ${ }^{\text {"57 }}$ It would be circular to reason that the public injury is the breach of jury secrecy as such. Rather, the Court reasoned that the stability of verdicts, however wrongly rendered, is more important than the litigant's right to a valid determination of his cause. ${ }^{58}$

Recognizing a strong public interest in the stability of verdicts once entered, Federal Rule of Evidence 606(b) provides that:

Upon an inquiry into the validity of a verdict or indictment, a juror may not testify as to any matter or statement occurring during the course of the jury's deliberations or to the effect of anything upon that or any other juror's mind or emotions as influencing the juror to assent to or dissent from the verdict or indictment or concerning the juror's mental processes in connection therewith, except that a juror may testify on the question whether extraneous prejudicial information was improperly brought to the jury's attention or whether any outside influence was improperly brought to bear upon any juror. Nor may a juror's affidavit or evidence of any statement by the juror concerning a matter about which the juror would be precluded from testifying be received for these purposes.

Of course, the CBS project does not threaten the stability of verdicts. The parties expressly waive the recording of the jury as the basis for an appeal. ${ }^{60}$ Consequently, the project poses no threat of disturbing the verdicts rendered. ${ }^{61}$

losing party cannot, in order to secure a new trial, use the testimony of jurors to impeach their verdict.").

37 . at 267.

${ }^{s s}$ See id. at 267-68 (reasoning that if juror testimony were permitted, no verdict would be safe).

${ }^{59}$ FED. R. EVID. 606(b).

कo See CBS Production Protocol, supra note 23, at *9 (" $[\mathrm{T}]$ he parties and their attorneys could sign waivers in which they agree not to use the filming of deliberations as a basis for appeal.").

${ }^{61}$ One might question whether there is a difference between waiving the recording as the basis of an appeal and waiving juror misconduct that the record reveals as the basis of an appeal. It is unclear, but the Comment assumes the parties waived not only the former, but also the latter as well. The extent to which this type of perturbation of verdicts counsels against recording the jury is explored below. See infra Part V. 


\section{Respect for Jurors' Privacy}

The secrecy of jury deliberations can also be defended on the ground of respect for jurors' privacy. In the course of deliberating, jurors may reveal facts germane to the matter that would be embarrassing if made more broadly available. In fact, the courts' solicitude for jurors is so great that courts restrict access to jurors even after the trial is over. ${ }^{62}$ The Supreme Court has noted that " $[t]$ he State has $\mathrm{a}[\mathrm{n}]$... interest in protecting juror privacy, even after the trial-to encourage juror honesty in the future-that almost always will be coextensive with the juror's own privacy interest." ${ }^{68}$ This, however, is not a valid objection to the CBS project because the jurors must consent to the recording. Consequently, the jurors are in no different position than anyone who consents to be televised in a sensitive matter. Moreover, if the state's interest in the juror's privacy is simply coextensive with the juror's own interest, the juror's consent is sufficient to counterbalance any state interest.

In summary, the mere fact that the CBS project involves a breach of jury secrecy is not a valid objection to the project, because the project adequately protects the interests that jury secrecy is meant to protect. Nonetheless, the fact that the CBS project involves a televised breach of jury secrecy is a more valid objection.

\section{B. Arguments Directed Against the CBS Project Specifically as a Television Project}

Some critics have opposed the CBS project based on its special character as a television broadcast, not merely as a breach of jury secrecy. One critic points out that " $[t]$ he very safeguards built into the CBS documentary proposal ... ensure that media consciousness

${ }^{62}$ See, e.g., United States v. Harrelson, 713 F.2d 1114, 1116 (5th Cir. 1983) ("[J]urors, even after completing their service, are entitled to privacy and to protection against harassment.").

In light of problems caused by the widespread desire to evade jury service, courts are increasingly sensitive to the need to be solicitous of jurors. Recently, New York and Arizona enacted path-breaking jury reforms, and many of the proposals are targeted at protecting jurors' interests or providing for jurors' convenience. See G. Thomas Munsterman, A Brief History of Jury Reform Efforts, 79 JUDICATURE 216, 216 (1996) (noting increases in juror pay, provision of juror ombudsmen, and complaint hotlines for jurors). For example, Arizona promulgated a proposed juror bill of rights. See B. Michael Dann \& George Logan III, Jury Reform: The Arizona Experience, 79 JUDICATURE 280, 285 (1996) (quoting in full the proposed bill of rights for Arizona jurors).

${ }^{63}$ Press-Enterprise Co. v. Superior Court, 464 U.S. 501, 515 (1984). 
among the selected jurors will be high." ${ }^{\text {"64 }}$ Moreover, the justices dissenting from Maine's administrative order pointed out that "[ $t] \mathrm{o}$ film a trial and the jury deliberations that follow when all the participants, judge, litigants, lawyers, and jurors have consented to the process cannot replicate a trial without the electronic intrusions." The dissenters concluded that " $[w]$ hat is represented to be the jury process will not be the jury process." ${ }^{, 66}$ In short, these critics argue that, over and above the change that observation in itself causes, television cameras particularly intrude on the jury, not simply by making the jury aware they are under observation, but by heightening their "media consciousness." "67

There is another, related criticism: Televising, as opposed to more neutral observation, negatively impacts on the solemnity of judicial proceedings. That is, televising court officers makes their behavior tend toward spectacle. For example, during the legislative debate in Maine, State Senator Sean Faircloth argued "that the CBS taping might lead to opening jury deliberations to more entertainment-oriented coverage and that 'the glare of the TV cameras' might distort jurors' judgment."

In fact, the first criticism is actually a form of this second criticism. Heightening the jury's media consciousness is not objectionable on the mere ground that a jury under observation-of whatever kindwill deliberate differently than it would in private; this would be a mere rehash of the traditional criticism of any generic breach of jury secrecy. Rather, critics like the Maine dissenters and Professor Abraham Abramovsky object more particularly to the special character of television recording.

These criticisms have some validity, though they are not decisive in the debate over whether the CBS project should have been allowed. First, the jurors themselves stated that they were not affected at all by the presence of the hidden CBS cameras. ${ }^{69}$ Second, the CBS production protocol provided a mechanism to correct for any distor-

\footnotetext{
At Abramovsky, supra note 8. ing).

${ }^{65}$ Administrative Order, supra note 19 , at *5 (Glassman \& Rudman, JJ., dissent-

Id. at *6 (Glassman \& Rudman, JJ., dissenting).

${ }^{67}$ Abramovsky, supra note 8.

is Senate Rejects Bill to Block Jury Taping, supra note 19. Senator Faircloth's concern prompted the chauvinist retort: "This is Maine, this is not L.A." Id. (quoting Sen. Joan Pendexter).

${ }^{69}$ See CBS Reports, supra note 9, at 4-5 (noting jurors' responses to the presence of cameras).
} 
tion created by the cameras. CBS included expert commentary on the deliberations recorded ${ }^{70}$ and is making the full coverage of the trials and deliberations available to legal scholars." Such measures provide a mechanism by which the accuracy of the representation of the jury may be critically appraised. Consequently, any observed behavior attributable to the presence of television could have been filtered through critical commentary so that the overall representation remained accurate.

More persuasive is the argument that projects like the CBS project diminish the solemnity of judicial proceedings. ${ }^{72}$ This argument, however, is far more effective in building the case against a general practice of televising the jury; where the project in question is a onetime documentary effort, the argument loses some force. ${ }^{73}$ Nonethe-

${ }^{70}$ See CBS Production Protocol, supra note 23 , at $* 6$ (proposing to include "deliberation by a panel of experts").

${ }^{7}$ See CBS Reports, supra note 9, at 71 ("CBS News is joining the ABA to make full coverage of these trials and deliberations available to students, scholars and the legal profession.").

${ }^{72}$ Broadcast coverage of court proceedings involves "mischievous potentialities for intruding upon the detached atmosphere which should always surround the judicial process," Estes v. Texas, 381 U.S. 532, 587 (1965) (Harlan, J., concurring), and "introduces into the conduct of a ... trial the element of professional "showmanship," $i d$. at 591 . While the holding of Estes has been expressly narrowed to its facts, so that cameras in the courtroom are not per se unconstitutional, see Chandler v. Florida, 449 U.S. 560, 573-74 (1981) (holding that Estes "is not to be read as announcing a constitutional rule barring ... television coverage in all cases and under all circumstances"), the Chandler Court emphasized television's "grave potentialities for distorting the integrity of the judicial process." Id. at 572 (quoting Estes, 381 U.S. at 592 (Harlan, J., concurring)).

${ }^{73}$ The Chandler Court took notice that television technology had advanced to the point that television coverage need not be, in any given instance, as intrusive as it was in Estes. See Chandler, 449 U.S. at 576 (noting that "many negative factors found in Estes... are less substantial factors today than they were at that time"). The issue now seems to be not whether broadcast coverage impairs the solemnity of a single trial covered, but whether the general practice of television coverage so trivializes what is recorded as to be undesirable. This issue arises in the context of cameras in the courtroom (and the evaluation of the impact of the Court TV network on the judiciary and the public) and in the context of debate over televised executions. One can see this issue addressed, for example, in the authorities cited in Christo Lassiter, TV or Not TV-That Is the Question, 86 J. CRIM. L. \& CRIMINOLOGY 928, 990 n.329 (1996). See also John D. Bessler, Televised Executions and the Constitution: Recognizing a First Amendment Right of Access to State Executions, 45 FED. COMM. L.J. 355, 357 n.3 (1993) (arguing that television will "trivialize executions-reduce them to the level of entertainment, to be clicked on and off" (quoting Anthony Lewis, Their Brutal Mirth, N.Y. TIMES, May 20, 1991, at A15)); Nancy T. Gardner, Note, Cameras in the Courtroom: Guidelines for State Criminal Trials, 84 MICH. L. REV. 475, 494 n.108 (1985) (noting that Justice Douglas opposed the extension of television into the courtroom because it would "transform a trial into 'as much of a spectacle as if it were held in the Yankee Stadium or the 
less, one critic has suggested that the project is in fact an early misstep on a slippery slope toward more regularly televised jury deliberations. ${ }^{74}$ This argument is plausible, as is its underlying implication that regular television broadcast of jury deliberations would deprive the institution of jury decisionmaking of its solemn dignity. To meet this objection, proponents have offered the type of justifications of press coverage that are typically invoked in press right-of-access cases. $^{75}$

\section{Justifications for Televising a Jury Do Not Support the CBS Project}

A close inspection of the Supreme Court's right-of-access jurisprudence reveals two things. First, justifications of the press's right of access to judicial proceedings do not apply to the CBS project. Second, the impulse to inspect the jury, which was the impulse animating the CBS project, is nonetheless a perfectly legitimate republican impulse.

Strictly speaking, the CBS project does not present an issue of the press's right of access to judicial proceedings. The question in the CBS situation is whether the access that the court granted should have been denied, whereas a right-of-access case raises the question whether the access denied must constitutionally be granted. Nonetheless, a line of Supreme Court cases addressing the right of access ${ }^{76}$

Roman Coliseum'" (quoting William O. Douglas, The Public Trial and the Free Press, 33 ROCKY MTN. L. REV. 1, 5 (1960))).

${ }^{74}$ See Abramovsky, supra note 8 ("With a dual precedent set, it is no longer unthinkable that television coverage of jury deliberations, especially in high-profile trials, may some day become routine.").

${ }_{75}$ See CBS Reports, supra note 9 , at 3 (suggesting that CBS undertook the project to permit the public to consider whether "the road to justice lead[s] through the jury room"); id. at 5 (statement of Arizona Chief Justice Stanley Feldman) (stating that he granted CBS permission to tape juries in order to permit the American people to judge for themselves whether the jury system is a desirable one). For a list of leading right-of-access cases, see infra note 76.

${ }^{76}$ See Press-Enterprise Co. v. Superior Court, 478 U.S. 1, 15 (1986) (holding unconstitutional a state court's closure of a 41-day preliminary hearing in a homicide case); Press-Enterprise Co. v. Superior Court, 464 U.S. 501, 513 (1984) (holding unconstitutional a state court's closure of a six-week voir dire); Globe Newspaper Co. v. Superior Court, 457 U.S. 596, 610-11 (1982) (holding unconstitutional a state statute requiring closure of trials of specified sexual offenses during the testimony of a minor victim); Richmond Newspapers, Inc. v. Virginia, 448 U.S. 555, 580-81 (1980) (plurality opinion) (holding unconstitutional a state court's absolute closure of a criminal trial).

While the Court's holdings all concerned criminal trials and closely related criminal proceedings, the doctrine led to an explosion in the lower courts, so that the right of access "has been extended to almost every variety of legal proceeding or document, 
articulates the clearest justifications for press coverage of judicial proceedings. Two justifications for press access to judicial proceedings emerge from these cases: Informing the public legitimates proceedings, and, in the case of criminal trials, provides "community therapeutic value." Neither of these justifications suffices to justify the CBS project. ${ }^{78}$

In Richmond Newspapers, Inc. $v$. Virginia, Chief Justice Burger observed that access to governmental action helps legitimate that action: "People in an open society do not demand infallibility from their institutions, but it is difficult for them to accept what they are prohibited from observing." ${ }^{79}$ The precise ways in which informing the public helps legitimate judicial proceedings include "assuring that proceedings are conducted fairly; discouraging perjury, misconduct of participants, and biased decisions; ... ensuring public confidence in a trial's results through the appearance of fairness; [and] inspiring confidence in judicial proceedings through education regarding the

but it has not been so extended beyond the courthouse." Eugene Cerruti, "Dancing in the Courthouse": The First Amendment Right of Access Opens a New Round, 29 U. RICH. L. REV. 237, 269 (1995).

Of course, many types of rights of different kinds of access have been litigated. This Comment only deals with the question of the First and Fourteenth Amendment rights of press or public access to judicial proceedings. In this Comment, the phrase "right of access" is a shorthand for this particular type of right-of-access jurisprudence.

"Richmond Newspapers, 448 U.S. at 570 (plurality opinion).

${ }^{78}$ What transpires in this subpart is not a species of circular reasoning, appearances to the contrary notwithstanding. It may appear unfair to say: (1) the question of the CBS project is not, strictly, a right-of-access question; (2) the reasons that justify the press's right of access do not apply to the CBS project; (3) therefore, the CBS project lacks any compelling justification. On first impression, this is to criticize one activity (the CBS project) for lacking the justifications that validate some other kinds of activity (general press access to judicial proceedings). However, no justifications have been offered for the CBS project other than the justifications typically offered for the press's right of access generally. CBS has justified the project primarily as an undertaking to inform the public and "answer the question, 'How do juries decide?" CBS Production Protocol, supra note 23, at *6; see alsoAdministrative Order, supra note 19 , at $* 4$ (Glassman \& Rudman, JJ., dissenting) (discussing CBS's stated intent to inform the public). The Arizona Supreme Court apparently adopted this rationale in deciding to permit the CBS taping. See CBS Reports, supra note 9, at 5 (statement of Arizona Chief Justice Stanley Feldman) ("'[I]f you think this is such a good system,... the people of the United States ought to have it-a look at it and judge for themselves.' ${ }^{\prime \prime}$ ).

Consequently, the real logic of the argument here could be stated as follows: Whatever justifications may be offered for the CBS project, they cannot piggyback on the right-of-access justifications, since those justifications presume general, ongoing, and widespread press access. No other justifications, however, exist.

${ }^{79} 448$ U.S. at 572 (plurality opinion). 
methods of government and judicial remedies." ${ }^{80}$ Moreover, the Court has acknowledged that "openness has what is sometimes described as a "community therapeutic value." 81 By this, the Court means that public awareness that the law is functioning and being enforced provides an outlet for the feelings of rage and indignation that the commission of crimes engenders in the community; providing such an outlet can help defuse the community's impulse toward extra-legal retaliation. ${ }^{82}$

These two justifications of press access to public proceedings cannot justify the CBS project. The justifications themselves implicitly presume the generality and continuity of access, which is lacking in the CBS project. The functions of legitimation and community therapeutic value presume that the judicial system itself is being monitored, not that a few trials are being recorded. The fact that one jury deliberates well would not serve to legitimate the institution of the jury any more than the fact that one jury deliberates poorly would form a valid basis for jury reform. Similarly, the recording of a single jury does not promote such a general awareness of the law being enforced as to provide community therapeutic value. In short, the recording of the deliberations of one jury (or a few juries) does not inform the public sufficiently about the nature and operation of the institution to serve the interests that the right of access generally serves. A closer inspection of the right-of-access issue, however, reveals the legitimacy of the impetus to inspect the jury underlying the CBS project. ${ }^{83}$

The Supreme Court's right-of-access cases suggest a two-prong inquiry: In deciding whether a press right of access exists, a court looks to whether there is "a tradition of openness ('history' prong), and...the instrumental utility of access to proper governmental functioning ('functional' prong). ${ }^{n 4}$ This two-prong analysis operates as a threshold inquiry:

${ }^{80}$ In re Globe Newspaper Co., 920 F.2d 88, 94 (1st Cir. 1990) (citing Richmond Newspapers, 448 U.S. at 571-72 (plurality opinion), and Press-Enterprise Co., 464 U.S. at 508-09).

${ }^{81}$ Press-Enterprise Co., 464 U.S. at 508-09 (quoting Richmond Newspapers, 448 U.S. at 570 (plurality opinion)).

${ }_{82}$ See id. (discussing how open proceedings provide an outlet for the reactions of the community to criminal acts).

${ }^{83}$ See supra note 78 (discussing the motivation of CBS in seeking access to jury deliberations and that of the Arizona Supreme Court in granting access).

${ }^{84}$ Cerruti, supra note 76, at 269. 
If the judicial proceeding passes these tests, a qualified First Amendment right of access attaches. The right may be overcome only if "closure is essential to preserve higher values and is narrowly tailored to serve that interest." Moreover, the Supreme Court has never found a value so compelling that it allows complete closure. ${ }^{85}$

Certainly, under this two-prong test, there is no right of access to jury deliberations. The history prong of the test is not met because there is no tradition of openness of jury deliberations-quite the contrary. ${ }^{86}$ Moreover, the functional prong is arguably not met. The presumption, unexamined and unsupported by empirical evidence, is that openness of jury deliberations would impede rather than enhance the jury's function:

Although many governmental processes operate best under public scrutiny, it takes little imagination to recognize that there are some kinds of government operations that would be totally frustrated if conducted openly. A classic example is that "the proper functioning of our grand jury system depends upon the secrecy of grand jury proceedings. ${ }^{87}$

The law has always presumed that the petit jury is also one of those governmental institutions that operates better in the dark. ${ }^{88}$ Consequently, it appears that the two-prong test derived from Richmond Newspapers and its progeny decisively establishes that there is no right of access to jury deliberations. ${ }^{89}$

One critic, Eugene Cerruti, however, has suggested that the twoprong test is not the proper formulation of the right-of-access doctrine. Noting that the Supreme Court has only decided a narrow class of right-of-access cases and has left the real development of the doc-

${ }^{85}$ Mary McDevitt Gofen, Comment, The Right of Access to Child Custody and Dependency Cases, 62 U. CHI. L. REV. 857, 863 (1995) (quoting Press-Enterprise Co., 464 U.S. at 510).

${ }^{86}$ See Goldstein, supra note 7, at 295 ("For most of the petit jury's long history, and certainly since the nineteenth century, the secrecy of jury deliberations has been taken for granted.... Prying into the jury's verdict, said Holdsworth, would have been as 'impious' as questioning the judgments of God." (quoting 1 WILIIAM HOLDSWORTH, A HISTORY OF ENGLISH LAW 317 (7th ed. 1956))).

${ }^{87}$ Press Enterprise Co. v. Superior Court, 478 U.S. 1, 8-9 (1986) (quoting Douglas Oil Co. v. Petrol Stops Northwest, 441 U.S. 211, 218 (1979)).

${ }^{2}$ See, e.g., In re Globe Newspaper Co., 920 F.2d 88, 95 (1st Cir. 1990) ("'Freedom of debate might be stifled ... if jurors were made to feel that their arguments ... were to be freely published to the world.' (quoting Clark v. United States, 289 U.S. 1, 13 (1933))).

${ }^{89}$ The First Circuit has said as much in dictum: There is "clearly no public right of access to the jurors' deliberations themselves. ... Clearly, there is no ordinary public right to 'know' what occurs in the jury room." Id. at 94. 
trine to the lower courts, ${ }^{90}$ Cerruti claims that the two-prong test fails to explain the doctrinal developments that have taken place: The test "fails to justify the extraordinary extension of the right of access to proceedings and documents with no real history of access and no real utility to the governing process. Many courts have in fact quite explicitly forsaken the two-prong standard while at the same time extending the right."

If Cerruti is correct, and there can be access to proceedings with no real history of access and no real utility to the governing process, the question of access to jury deliberations is no longer cut and dried. The question of access, then, would have to be measured according to some standard other than the two-prong test. According to Cerruti, any statement of the doctrine of access should reflect the reality of the developments taking place in the lower federal courts. ${ }^{92}$

The "actual touchstone for the new doctrine of access" ${ }^{\text {"99 }}$ is Justice Brennan's concurrence in Richmond Newspapers. ${ }^{94}$ While that opinion embodies aspects of the two-prong test, "the central premise of Richmond Newspapers is that meaningful self-government requires an informed electorate, and that where the representative government itself maintains control of information essential to such an informed public discourse, the government may be affirmatively required to provide that information to the public." The right-of-access doc-

${ }^{90}$ See Cerruti, supra note 76, at 266-69 (discussing the lower court cases).

${ }^{91}$ Id. at 269 (footnote omitted).

${ }^{92}$ See id. at 318 (proposing a "revised reading of the right of access [that] is in accord with the major holdings of the established case law").

${ }^{93} I d$. at 272.

${ }^{94}$ Justice Brennan, in his concurring opinion, explained:

First, the case for a right of access has special force when drawn from an enduring and vital tradition of public entree to particular proceedings or information.... Second, the value of access must be measured in specifics.... [W] hat is crucial in individual cases is whether access to a particular government process is important in terms of that very process. To resolve the case before us, therefore, we must consult historical and current practice with respect to open trials, and weigh the importance of public access to the trial process itself.

Richmond Newspapers, Inc. v. Virginia, 448 U.S. 555, 589 (1980) (Brennan, J., concurring in judgment).

${ }_{95}$ Cerruti, supra note 76, at 239. In Richmond Newspapers, Justice Brennan further emphasized that:

[T]he First Amendment embodies more than a commitment to free expression and communicative interchange for their own sakes; it has a structural role to play in securing and fostering our republican system of selfgovernment. Implicit in this structural role is not only "the principle that debate on public issues should be uninhibited, robust, and wide-open," but also 
trine, therefore, must be restated "to center upon the governmental decision-making power of the Judiciary, rather than the functional utility of access to a given judicial process." ${ }^{96}$ According to Cerruti, "[t]he public has a right of access to all information, located within the adjudicative process, relevant to an evaluation of the exercise or performance of judicial authority over substantive matters of official court business, unless there is a sufficiently compelling reason not to so provide access." ${ }^{\text {,97 }}$

By Cerruti's standard, the question of whether access to jury deliberations is appropriate becomes a much closer question. Certainly, the contents of those deliberations constitutes information located within the adjudicative process. Moreover, that information is highly relevant to an evaluation of the exercise of judicial authority over substantive matters of official court business, since the evaluation of a judgment entered on a verdict logically involves an evaluation of the deliberative process that yields the verdict.

The key question, then, becomes whether there is a sufficiently compelling reason not to provide access to jury deliberations. Such compelling reasons may exist in the need to prevent the jury's debate from being chilled by press observation, or in the need to preserve the solemnity of jury deliberations by shielding them from press observation. $^{98}$ However that may be, Cerruti's analysis brings into relief the crucial issue: The motivation for inspecting the jury, which underlies the CBS project and is entirely legitimate, is not a claim for a negative liberty-that is, to be free of government restraint in the free flow of communication between broadcaster and audience. Rather, the motivation is a strong claim that the government has an affirmative obligation to give an account of its activities to the people. However wrong it may be to permit CBS to televise a jury, the motivation to monitor the jury is a legitimate republican, not just libertarian,

the antecedent assumption that valuable public debate-as well as other civic behavior-must be informed. The structural model links the First Amendment to that process of communication necessary for a democracy to survive, and thus entails solicitude not only for communication itself, but also for the indispensable conditions of meaningful communication.

448 U.S. at 587-88 (Brennan, J., concurring in judgment) (citations omitted) (footnote omitted) (quoting New York Times Co. v. Sullivan, 376 U.S. 254, 270 (1964)).

\footnotetext{
${ }_{96}$ Cerruti, supra note 76, at 295.

${ }^{9}$ Id. at 295-96.

${ }^{93}$ See supra Part II.A-B.
} 
impulse. ${ }^{99}$ The proposal to transcribe jury deliberations as part of the trial record seeks to give that republican impulse its due, without sacrificing either the dignity of the jury or the benefits of jury privacy.

In summary, critics have attacked the CBS project based on both its generic character as a breach of jury secrecy and its special character as a televised intrusion on the jury. The latter arguments are slightly stronger than the former. Moreover, the justifications that might be offered for televising the jury cannot justify a one-time project like the CBS project. Nonetheless, by refusing to acknowledge the legitimate motivations behind public efforts to observe the jury, critics have failed to hit upon the best argument against the CBS project.

The strongest argument admits that the jury should be observed but denies that television broadcast of deliberations is the proper means of observation. Consequently, the most serious criticism of the CBS project is not the "slippery slope" argument that the project is simply the first of many. Rather, the best argument against the project is that it is merely an isolated instance of observation of a jury, when what is needed is continual monitoring of all juries.

\section{DESIRABILITY OF AN ALTERNATIVE: COURT-RECORDED JURY DELIBERATIONS}

Close analysis of the CBS project and the debate surrounding it reveals the need for the recognition of the validity of the impulse that lies behind that project: an impulse to provide closer public monitoring of the jury system. ${ }^{100}$ By the same token, the critics' concerns about a televised intrusion on the jury appear valid. ${ }^{101}$ Consequently, a manner of monitoring the jury that would render the jury more accountable to the public, but that would intrude on the jury's privacy less than a television broadcast of deliberations, seems desirable. Such an alternative is the transcription of jury deliberations as part of the ordinary trial record, not for the purpose of general public distribution, but for the purpose of limited judicial review. To see more

${ }^{99}$ Cf. Cerruti, supra note 76 , at 283 ("Richmond Newspapers does not vindicate a freedom of speech so much as it does a freedom of self-rule."); id. at 240 ("It was the very exhaustion of the traditional libertarian paradigm of freedom, and its inability to secure a proactive self-government against the informational hegemony of the modern state, that forced the Court to reach beyond, but not to break, that mold.").

${ }^{100}$ See supra Part II.C.

${ }^{102}$ See supra Part II.B. 
precisely how desirable this alternative is, one must revisit the criticism of absolute jury secrecy.

\section{A. Criticism of Jury Secrecy}

There are two problems with the secrecy of the American jury. First, the secrecy of jury deliberations is inconsistent with the overall spirit of our judicial proceedings. ${ }^{102}$ Second, jury secrecy as currently practiced (namely, near-absolute secrecy) is not tailored narrowly enough. ${ }^{103}$ In short, jury secrecy as practiced is so broad that the public's interest in supervised government processes is insufficiently protected. This breadth is unnecessary; jury secrecy could be more narrowly tailored without disserving the ends that ordinarily justify it.

\section{Secret Deliberations Are Not Formally Rational}

Judicial proceedings require formal rationality. That is to say, the form in which the proceedings take place must reflect their rationalist substance. The form of the proceedings must reflect the proceedings' single-minded devotion to the efficient accomplishment of the common end of justice: the resolution of disputes according to rules of general applicability. ${ }^{104}$ To illustrate and defend this claim, one might observe that our law of procedure and evidence manifests this devotion to formal rationality.

The federal rules of procedure are to be interpreted and administered so as to secure fair resolutions efficiently. ${ }^{105}$ Rules of pleading are liberal and intended to prevent technicalities from impeding the adjudication of controversies on the merits. ${ }^{106}$ Information is presumptively discoverable, affording parties every opportunity to sub-

${ }^{102}$ See infra Part III.A.1.

${ }^{103}$ See infra Part III.A.2.

${ }^{104}$ For the purposes of this discussion, this will be the definition of formal rationality. On formal, as opposed to substantive, rationality, see FROM MAX WEBER: ESSAYS IN SociolocY 298-99 (H.H. Gerth \& C. Wright Mills eds. \& trans., Galaxy Books 1958) (1946). On the import of formal rationality in legal bureaucracy, see $i d$. at 216-21.

${ }^{105}$ See FED. R. CIV. P. 1 (stating that rules "shall be construed and administered to secure the just, speedy, and inexpensive determination of every action"); FED. R. CRIM. P. 2 (stating that rules "shall be construed to secure simplicity in procedure, fairness in administration and the elimination of unjustifiable expense and delay").

${ }^{106}$ See Fleming James, JR. eT AL., Civil Procedure $\$ 1.8$, at 22 (4th ed. 1992) (noting that the principal features of the federal rules "are integrated to promote the decision of disputes on their merits"). 
stantiate claims and defenses. ${ }^{107}$ Similarly, the Federal Rules of Evidence "shall be construed to secure fairness in administration, elimination of unjustifiable expense and delay, and promotion of growth and development of the law of evidence to the end that the truth may be ascertained and proceedings justly determined. ${ }^{108}$ Evidence must be logically relevant to be admissible. ${ }^{109}$ Moreover, evidence that is logically relevant may be excluded if it is likely to lead to a result based on passion or prejudice rather than reason. ${ }^{110}$ The furtherance of these ends is committed to the supervisory authority of the court, and the conduct of court officers can be tightly reined to promote these ends. ${ }^{11}$

Once the jury has retired, however, the jury's conduct is completely out of the court's control. If a drunken and inattentive jury convicts a man of a crime, that decision is unreviewable-at least, the jurors may not be summoned to answer for their conduct and verdict. $^{112}$ There is something comically inconsistent about the scrupulous observation of proper procedure and formal proof during the trial, and the final submission of the cause to a deliberative body that operates free of all rational constraint with a request that it return a verdict unjustified by reasons. A trial would have more rational consistency if the jury were as subject to the court's supervisory control during the weighing of evidence as it is during the reception of evidence. Transcription of deliberations for the purpose of judicial review would provide the requisite control.

${ }^{107}$ See FED. R. CIV. P. 26(b)(1) (stating that parties may have discovery of any relevant matter not privileged, and that matter need not be admissible if "reasonably calculated to lead to discovery of admissible evidence" ${ }^{\prime \prime}$.

${ }^{103}$ FED. R. EVID. 102.

${ }^{109}$ See FED. R. EVID. 402 ("All relevant evidence is admissible. ... Evidence which is not relevant is not admissible.").

${ }^{110}$ See, e.g., FED. R. EVDD. 403 ( ${ }^{\text {[ }}[\mathrm{E}]$ vidence may be excluded if its probative value is substantially outweighed by the danger of unfair prejudice, confusion of the issues, or misleading the jury, or by considerations of undue delay, waste of time, or needless presentation of cumulative evidence.").

${ }^{11}$ See, e.g., FED. R. CV. P. 11 (permitting sanction of attorneys for frivolous, wasteful, or dilatory tactics); FED. R. EVID. 105 (permitting a court to attempt to restrict a jury's consideration of admitted evidence).

${ }^{112}$ See Tanner v. United States, 483 U.S. 107, 122-25 (1987) (holding that the legislative history of rule 606(b) of the Federal Rules of Evidence demonstrates that Congress intended that jurors not be questioned about possible intoxication during deliberation). 


\section{Jury Secrecy Is Not Tailored Narrowly Enough}

Jury secrecy as practiced is so broad that it infringes on other legitimate public interests-primarily the public's interest in the accountability of government decisionmakers. The degree of jury secrecy that is justifiable could be achieved by less extreme means, permitting protection of the legitimate interests currently infringed.

\section{a. Near-Absolute Jury Secrecy, as Currently Practiced, Infringes on Other Legitimate Public Interests}

Jury secrecy is contrary to the principle, operative in the Supreme Court's right-of-access jurisprudence, that "the Judicial Branch [is] a governing agency subject to the sovereign limitations of the selfgoverning electorate." ${ }^{113}$ Perhaps this principle does not justify press access to jury deliberations, ${ }^{114}$ but it recommends that, in the absence of press access, the jury still be monitored. In short, even if we assume that some governmental processes operate better out of the public eye, ${ }^{115}$ it does not follow that those processes must be completely unsupervised and unreviewable. To the contrary, where we permit government activity to carry on in secret, we normally insist on intra-governmental oversight. ${ }^{116}$

It is not clear that limited court supervision of jury deliberations and the requirement of a modicum of reasoned justification of the jury's decision will frustrate the operation of the jury as an institution. ${ }^{117}$ Tailoring jury secrecy more narrowly, by subjecting it to limited judicial review, would infringe less on the public interests of legitimation and community therapeutic value that openness generally promotes than does the current degree of secrecy. ${ }^{118}$ Moreover, the extreme degree of secrecy that currently protects jury deliberations arguably diminishes the legitimacy of the jury.

${ }^{11}$ Cerruti, supra note 76, at 301.

114 See supra Part II.C.

${ }^{115}$ See Press-Enterprise Co. v. Superior Court, 478 U.S. 1, 8-9 (1986) (recognizing that "some governmental operations would be totally frustrated if conducted openly").

${ }^{116}$ See, e.g., Houchins v. KQED, Inc., 438 U.S. 1, 3435 (1978) (Stevens, J., dissenting) (stating that many governmental functions require secrecy that is subject to the appropriate legislative oversight).

${ }^{117}$ See Goldstein, supra note 7, at 313 n.75 (noting the absence of a'ny'evidence on the question of the "effect on a group (assured of privacy while it performs the group function) of an awareness that its activities will be disclosed afterwards").

${ }^{118}$ See supra Part II.C. 
The legitimacy of the jury is under attack. Certainly, criticism of the jury as an institution is not new: "[V]irtually from its inception, [the jury] has been the subject of deep controversy, attracting at once the most extravagant praise and the most harsh criticism." Nonetheless, there have been recent cases where a large segment of the national population has observed the trial and evidence almost as closely as the jury, and there has been widespread disagreement with the verdicts rendered. ${ }^{120}$ This trend is likely to continue since the televising of trials gives every indication of increasing rather than abating. ${ }^{21}$ As long as juries render verdicts with which a public that has seen and heard the evidence disagrees, dissatisfaction with juries that operate free of the rational restraints of the judicial process is likely to abide. Arguably, the public will more readily tolerate jury verdicts that are subject to at least some critical review (such as judi-

${ }^{119}$ KALVEN \& ZEISEL, supra note 15, at 4; see also Hearings, supra note 13, at 63 (memorandum submitted by Harry Kalven, Jr.) ("[T]he debate [over the jury system] has been going on for a long time (at least since 1780) and the arguments which were advanced pro and con haven't changed much in the interim. Nor, contrary to my first impression, does there seem to be any particular period in which the debate grows hotter or colder. It has always been a hot debate.").

${ }_{120}$ The criminal trial of O.J. Simpson is the most striking and most recent example of this social problem. A broad segment of the population watched the entire trial almost as closely as the jury did, and a significant percentage of the population disagrees with the verdict rendered. See Howard Goldberg, Black-White Gap over O.J.'s Guilt Narrows, AP, Jan. 22, 1997, available in 1997 WL 4852830 (noting that 53\% of Americans-59\% white and $16 \%$ black-still disagreed with the acquittal of O.J. Simpson).

The most serious instance of this social problem was the criminal trial of the officers accused of beating Rodney King. In that case, a significant segment of the population felt that the admitted evidence they had seen with their own eyes (the videotape) spoke clearly to the defendants' guilt, and yet the jury acquitted with no justification or explanation offered. Indignation over justice denied, and the breakdown of the "community therapeutic" function due to jury secrecy, led to widespread rioting. See Views on the King Verdict, WASH. PoST, May 3, 1992, at A26 (noting that $68 \%$ of all Americans disagreed with the verdict that preceded the L.A. riots); $c f$. Carla Rivera, Majority Say Denny Verdicts Too Lenient, L.A. TIMES, Oct. 26, 1993, at A1 (reporting that $82 \%$ of Angelenos disagreed with the verdict in the King beating case and that $76 \%$ were angered by it, and also noting widespread disagreement with verdicts in the trial of the defendants charged with the videotaped beating of a motorist during the L.A riots, with $67 \%$ of Angelenos thinking that the jury was motivated by fear, $52 \%$ disapproving of the jury's handling of the case, and $63 \%$ saying that they had little confidence in the jury system).

${ }^{121}$ See, e.g., Harvey J. Sepler, Where Do We Stand on Cameras in the Courtroom?, FLA. B.J., June 1996, at 113, 113 ("[T] public interest in the trial process, this type of [electronic media] coverage will burgeon."); The Appearance of Justice: Juries, Judges and the Media Transcript, 86J. CRIM. L. \& CRIMINOLOGY 1096, 1099 (1996) (statement of Leslie Abramson) ("The television of trials, of many, many trials every year, is guaranteed."). 
cially reviewed deliberation transcripts) in contrast to current verdicts, which are not only kept from public view, but are also not reviewable by any public official.

\section{b. Near-Absolute Jury Secrecy, as Currently Practiced, Is More Extreme Than Required by the Ends That Justify It}

Jury secrecy is ordinarily justified by the justice system's interest in promoting frank communication or free debate among jurors, protecting juror privacy, and promoting the stability of verdicts. ${ }^{122}$ The ordinary rule of absolute jury secrecy, however, goes too far. These legitimate interests could be adequately protected by a less absolute form of jury secrecy which allows the transcription of jury deliberations for judicial review. ${ }^{123}$

There is no evidence that disclosure of the contents of jury deliberations after they are completed would affect those deliberations in any way. ${ }^{124}$ Assuming, however, that merely transcribing deliberations might chill the jurors' discussion, a rule of juror secrecy, as opposed to jury secrecy, would serve the end of frankness just as well as the current rule of jury secrecy. ${ }^{125}$ That is to say, as long as the identity of individual jurors is kept secret, there is no reason to think that recording of their deliberations would have a chilling effect on individual jurors.

Similarly, a policy of juror secrecy rather than jury secrecy would adequately protect jurors' privacy. While jurors may indeed feel the

${ }^{122}$ See supra Part II.A.

${ }^{123}$ In this section, only the interests of juror frankness and juror privacy are discussed. It is argued that transcribing jury deliberations will not seriously interfere with any legitimate public interest in the finality of verdicts, since the harmless-error standard will protect that interest independently of any rule of secrecy. This argument, however, is addressed in the section on the nature and scope of review of jury deliberations. See infra Part V.

124 See supra note 117.

${ }^{125}$ Distinguishing between the jury and the jurors is crucial for the analysis of several problems, not just this problem of secrecy. The distinction has been highlighted for purposes of social-scientific study of jury decisionmaking, see Jeffrey Kerwin \& David R. Shaffer, Mock Jurors Versus Mock Juries: The Role of Deliberations in Reactions to Inadmissible Testimony, 20 PERSONALITY \& SOC. PSYCHOL. BULL. 153, 159-61 (1994) (arguing that inferences of influences on jury behavior from observations of influences on juror behavior may be invalid), and of systematization of the Supreme Court's interpretations of the impartiality mandate of the Sixth Amendment and the Due Process Clauses, see generally Scott W. Howe, Juror Neutrality or an Impartiality Array?: A Structural Theory of the Impartial Jury Mandate, 70 NOTRE DAME L. REV. 1173, 1179-219 (1995) (exploring whether a constitutionally impartial jury means more than a group of impartial jurors). 
need to touch on private matters while deliberating, they also feel this need during voir dire. In that context:

[T]he constitutionally preferable method for reconciling the First Amendment interests of the public and press with the legitimate privacy interests of jurors and the interests of defendants in fair trials is to redact transcripts in such a way as to preserve the anonymity of jurors while disclosing the substance of their responses. ${ }^{12}$

As the jurors remain strangers to one another, one might infer that they make whatever sensitive statements that are necessary in a rather guarded way. There is no reason to think that jurors make statements that, divorced from any identifiable speaker, are so private that the fact of transcription for judicial review would chill the speaker. The balance of public interests and juror interests in the context of deliberations, as in the context of voir dire, favors transcription of juror statements in a way that preserves juror anonymity.

\section{B. Practical Considerations in Recording Jury Deliberations for Judicial Review}

The rule of absolute jury secrecy should be amended, and jury deliberations should be transcribed as part of the trial record, permitting a limited judicial review. Such a practice would have three main benefits. First, the practice would legitimate jury deliberations as a government proceeding in all the ways that more public inquiries into jury deliberations (for instance, post-verdict interviews or the CBS project) claim to do, ${ }^{127}$ without the attendant encroachments on juror privacy, trial solemnity, and juror frankness. Second, the practice would integrate jury deliberations more into the overall trial process, making the trial a more unified, consistently rational proceeding. This would rationalize the overall procedure by eliminating the disjunction between the rationalized trial phase and the oracular delivery of the verdict. ${ }^{128}$ Third, the practice would arguably improve

${ }^{126}$ Press-Enterprise Co. v. Superior Court, 464 U.S. 501, 520 (1984) (Marshall, J., concurring in judgment).

${ }^{127}$ This serves the goal of rendering the jury accountable to the public, see Note, supra note 5 , at 893 (noting the view that the jury should be scrutinized like any public agency), "educat[ing] the public, restrain [ing] ... the abuse of governmental power, and maintain [ing] public confidence in our legal system," Goldstein, supra note 7, at 302.

${ }^{128}$ Edson R. Sunderland first compared modern jury secrecy to ancient oracles: The general verdict is as inscrutable and essentially mysterious as the judgment which issued from the ancient oracle at Delphi. Both stand on the same 
the results of jury trials by impressing more on the jurors their role as officers of the court and by permitting courts to overturn verdicts improperly derived. ${ }^{129}$

Admittedly, there are costs associated with such a modification of jury secrecy. Judicial review will result in less finality for verdicts and will increase demand on judicial resources. As a body of common law concerning judicial review develops, however, those costs will probably decrease as the class of colorable attacks on verdicts becomes more sharply defined. ${ }^{130}$

However, substantial benefits will also be gained from the experiment: primarily, increased understanding of how the jury operates and increased public faith in judicial proceedings. Some benefits, such as increased knowledge, will accrue to other jurisdictions in addition to the jurisdiction that undertakes the experiment. Therefore, one might expect each state to be reluctant to initiate such an experiment, instead waiting to free-ride on another state's experiment. The federal government plays an important part in solving such collective-action problems among the states. ${ }^{131}$ More-over, the federal courts play a leading role in reforming and modernizing judicial procedure. ${ }^{132}$ For these reasons, the experiment of recording jury deliberations should begin in the federal courts. ${ }^{133}$

foundation-a presumption of wisdom. The court protects the jury from all investigation and inquiry as fully as the temple authorities protected the priestess who spoke to the suppliant votary at the shrine.

Edson R. Sunderland, Verdicts, General and Special, 29 YALE L.J. 253, 258 (1920). While Sunderland thought it nonetheless quite proper that the court should not permit jurors to testify "as to how they compounded their verdict," id., preferring instead to do away with the general verdict altogether, see id. at 258, 266 (arguing that a special verdict system would improve jury decisions), Sunderland's "provocative language ha[s] much farther-reaching implications," Note, supra note 5, at 893 n.46.

${ }^{129}$ See Sunderland, supra note 128, at 259 (suggesting that lifting the cloak of jury secrecy would inculcate the proper, public-spirited sense of responsibility in jurors).

${ }^{130}$ See infra Part V (discussing how the harmless-error doctrine will protect adequately the interests of judicial economy).

${ }^{131}$ In the regulatory field, it is recognized that the federal government plays an important role in helping states overcome 'prisoners' dilemmas' like the free-rider problem. See Jerry L. Mashaw \& Susan Rose-Ackerman, Federalism and Regulation, in THE REAGAN Regulatory Strategy 111, 117 (George C. Eads \& Michael Fix eds., 1984) (illustrating the prisoner's dilemma).

192 See, e.g., GeOFFrey C. HaZARd, JR. et al., Cases and Materials on Pleading AND PROCEDURE 30 (7th ed. 1994) (noting that many states have followed the federal courts' lead by adopting the Federal Rules of Civil Procedure in whole or in substantial part).

${ }^{133}$ There is a possible contrary argument. One of the great benefits of our federal system is that individual states can experiment with novel procedures adapted to 
Transcription of jury deliberations should continue to promote, as much as possible, the interests that jury secrecy has always promoted. ${ }^{134}$ Nonetheless, the transcript must be made in a way that provides for meaningful judicial review. For there to be meaningful review, there must be transcription of deliberations in every case tried, despite the nonassent, or even the affirmative objection, of a party, and despite the nonassent of the jurors.

Transcription of deliberations should be undertaken with all due respect for juror (as opposed to jury) privacy. Nonetheless, to provide for meaningful judicial review, the transcript must reflect continuity in individual jurors' remarks. Although jurors should remain anonymous, it will be important that readers be able to ascertain whether two statements in the transcript were made by the same juror. Consequently, there must be some identification-however anonymous-of each juror. Therefore, the transcript should identify jurors only by randomly assigned number, not by name. ${ }^{135}$

Transcription should impede as little as possible the freedom of the jurors' debate. The transcription method, therefore, should be unobtrusive so as to avoid interrupting their deliberations or impressing unduly on the jurors' minds the fact of recording. ${ }^{136}$ Moreover,

changing needs without committing the entire country to the experiment, but permitting the other states to learn from each other's experience. Since transcription of jury deliberations represents a significant departure from current common-law trial practice, one might argue that transcription is a prime candidate for experimentation at the state, rather than the federal, level.

For analytical purposes, it is preferable to consider reform at the federal level, where the procedure's strictest obstacles exist. Should an individual state undertake such a reform, it will still benefit from this analysis, since state law will initially be either less of an obstacle than federal law, or will be, for all relevant purposes, identical to federal law. By analyzing the problem at the federal level, this Comment does not leave unexplored any significant legal problems that might face reformers in any jurisdiction, state or federal.

${ }^{134}$ Those interests are, of course, juror privacy, frankness of debate, and stability of verdicts. The impact of transcription on the last of these three interests is a special problem addressed in Part V of this Comment.

${ }^{135}$ This is essentially a technique for preserving juror, as opposed to jury, secrecy, and is consistent with Justice Marshall's suggestion regarding the privacy issues in the related area of voir dire responses. See Press-Enterprise Co. v. Superior Court, 464 U.S. 501,520 (1984) (Marshall, J., concurring in judgment) (arguing that voir dire transcripts should be made public with juror identity withheld).

${ }^{195}$ Jury transcription involves technical problems beyond the scope of this Comment. How exactly the jury room should be wired is not considered. A few remarks, however, are warranted. The means of recording must permit identification of jurors. This may require the presence of a stenographer in the jury room. The preferable method, however, is to make a transcript from tape recordings; it is cheaper as well as less intrusive. Recording devices should be as inconspicuous as possible. In address- 
the transcript should be protected by the court, and the court should retain the power to deny a party access to the transcript on a finding that juror harassment or other injury to the administration of justice would result. ${ }^{137}$

Of course, not everything that is desirable or expeditious is legal. Accordingly, this Comment next examines the legality of recording jury deliberations with the knowledge, but without the consent, of the parties and the jury.

\section{LEGALITY OF COURT-RECORDED JURY DELIBERATIONS}

While any type of recording of jury deliberations is statutorily proscribed in the federal courts ${ }^{138}$ and proscribed or restricted in some state courts, ${ }^{139}$ the Constitution does not require such secrecy. This

ing the technical problems of recording the jury, one should bear in mind the possibility that the jury will often not deliberate as a whole but will break up into smaller groups, all of which will have to be recorded. For example, imagine a jury of twelve with three holdouts; in all likelihood, the jury would not deliberate as one body, but would break up into three groups, with three members of the majority "working" each of the holdouts. I am indebted to Louis Ruprecht, Esq., for this last caveat.

${ }^{137}$ Juror safety and the integrity of the judicial system are crucial concerns of jury secrecy, sometimes justifying juror anonymity or the closure of voir dire. See Goldstein, supra note 7, at 302-03 (discussing cases restricting press access to jurors or their identities during voir dire and trial, and after trial). tions).

${ }^{138}$ See 18 U.S.C. $\$ 1508$ (1994) (outlawing recording and listening to jury delibera-

${ }^{139}$ Nine states proscribe the recording of jury deliberations, by expressly prohibiting recording of deliberations, see ALA. CODE $\S 13 A-10-130$ (a) (5) (1994); HAw. REV. STAT. \$ 710-1077(1)(f) (1993); MICH. COMP. LAWS ANN. $\$ 750.120 \mathrm{~b}$ (West 1991), by prohibiting listening to deliberations, see 18 PA. CONS. STAT. ANN. $\$ 5103$ (West 1983), by prohibiting either recording or listening, see 705 ILL. COMP. STAT. ANN. 315/1-1 (a)

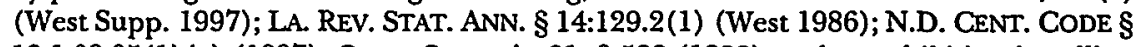
12.1-09-05(1) (a) (1997); OKLA. STAT. tit. 21, $\$ 588$ (1983), or by prohibiting installing or causing to be installed a recording device in the jury room, see VA. CODE ANN. $\S$ 18.2-468 (Michie 1996). Three other states require court authorization for any recording or interception of jury deliberations. See MINN. STAT. ANN. $§ 631.09$ (West 1983); S.C. CODE ANN. $§ 16-9-360$ (Law Co-op. 1985); S.D. CoDIFIED LAWS §§ 23A-35A-20(3), -21 (5) (Michie 1988).

Texas would prohibit a stenographer from being in the jury room but would not necessarily prohibit recording the jury's deliberations. See TEX. CRIM. P. CODE ANN. $\S 36.22$ (West 1981) (stating that no person "shall be permitted to be with the jury" while it is deliberating). Similarly, Mississippi prohibits any "court officer" from being in the jury room "save by order of the court." MiSs. CODE ANN. § 97-9-57 (1994).

Federal law prohibits electronic interception of any oral communications where the participants have a justifiable expectation of privacy. See 18 U.S.C. $\$ 2511$ (1994) (prohibiting interception of oral communications); id. $\$ 2510$ (2) (defining oral communications to include only communication under which the parties have a 
Part demonstrates the constitutional permissibility of recording jury deliberations in both criminal and civil cases, and then suggests amendments to the statutes and rules that bar such recording.

\section{A. Constitutional Issues}

\section{Criminal Trials}

Article III of the Constitution provides in pertinent part that "[ $t]$ he Trial of all Crimes, except in Cases of Impeachment, shall be by Jury," ${ }^{140}$ and the Sixth Amendment provides that "[i]n all criminal prosecutions, the accused shall enjoy the right to a speedy and public trial, by an impartial jury of the State and district wherein the crime shall have been committed."141

The Sixth Amendment guarantee is fully incorporated into the Fourteenth Amendment, and, therefore, the right to a criminal jury trial applies identically in state-court and federal-court prosecutions. ${ }^{14}$ However, the Sixth Amendment guarantee does not include all the historical incidents of the common-law jury; courts can "turn[] to other than purely historical considerations to determine which features of the jury system, as it existed at common law, were preserved

justifiable expectation that the communication is not subject to interception). Federal law, therefore, requires that the jurors know that they are being recorded.

One state requires the jurors' consent to any recording in addition to the jurors' knowledge. See CAL. PENAL CODE $\S 167$ (West 1988). Another state requires either knowledge or consent, see N.C. GEN. STAT. $\$ 14-227.2$ (1996), though it is doubtful that recording a juror without the juror's knowledge but with some kind of constructive consent would comport with the federal wiretap statute. Several states have wiretapping statutes that either mirror the federal law or additionally apply specifically to juries, but these state statutes do not add any obstacle to jury recording beyond the knowledge requirement of federal law. See, e.g., N.Y. PENAL LAW \$ 250.05 (McKinney 1989 ) (prohibiting mechanically overhearing a conversation); id. $\$ 250.00$ (permitting mechanical overhearing with consent of at least one party to a conversation).

In summary, nine states (Alabama, Hawaii, Illinois, Louisiana, Michigan, North Dakota, Oklahoma, Pennsylvania, and Virginia) directly prohibit recording jury deliberations, in a fashion analogous to the federal prohibition in 18 U.S.C. $\$ 1508$. Six other states (California, Minnesota, Mississippi, South Carolina, South Dakota, and Texas) impose some restriction on the recording of jury deliberations beyond the restriction imposed by the federal wiretapping statute.

${ }^{140}$ U.S. CONST. art. III, § 2, cl. 3.

141 Id. amend. VI.

142 See Duncan v. Louisiana, 391 U.S. 145, 149 (1968) ("Because we believe that trial by jury in criminal cases is fundamental to the American scheme of justice, we hold that the Fourteenth Amendment guarantees a right of jury trial in all criminal cases which-were they to be tried in a federal court-would come within the Sixth Amendment's guarantee."). 
in the Constitution. The relevant inquiry ... must be the function that the particular feature performs and its relation to the purposes of the jury trial." 143

The relation of the function of jury secrecy to the purpose of the criminal jury is such that transcription of jury deliberations for purposes of judicial review does not offend the Constitution.

Since " $[t]$ he purpose of the jury trial ... is to prevent oppression by the Government," the essence of a criminal jury "lies in the interposition between the accused and his accuser of the commonsense judgment of a group of laymen, and in the community participation and shared responsibility that results from that group's determination of guilt or innocence."144 The relationship of jury secrecy's function to this purpose does not require a ban on transcribing jury deliberations.

The functions of jury secrecy are to promote frankness in jury deliberation, to promote stability of verdicts, and to respect juror privacy. ${ }^{145}$ While the first and third functions promote the purposes of the criminal jury identified in Williams, the limited inspection of jury deliberations advocated here would not frustrate those purposes. Jury deliberations can be transcribed in such a way as to have a minimal impact on frankness in juror discussions and on juror privacy. ${ }^{146}$ Moreover, the second function arguably frustrates the purposes identified in Williams as much as it promotes them. As Tanner v. United States $^{147}$ illustrates, the premium placed on verdict stability prohibits evidence tending to show that jurors were incapable of interposing their common sense between the accused and the state. Judicial review would lessen this problem by permitting a court to determine whether the jury adequately performed its essential function.

Finally, court transcription of jury deliberations would actually advance, rather than frustrate, one of the purposes of trial by jury that the Williams Court identified: promotion of a shared sense of respon-

143 Williams v. Florida, 399 U.S. 78, 99-100 (1970) (holding that the Sixth and Fourteenth Amendments do not require that criminal juries consist of twelve jurors); see also Apodaca v. Oregon, 406 U.S. 404 (1972) (holding that the Sixth and Fourteenth Amendments do not require a unanimous verdict).

${ }^{144}$ Williams, 399 U.S. at 100.

${ }^{145}$ See supra Part II.A.

${ }^{146}$ See supra Part III.A.2.b. Tanner). 
sibility in the rendition of a verdict. ${ }^{148}$ With the jury's verdict essentially unreviewable as it is now, the verdict appears very much the product of just twelve (or fewer) people. ${ }^{149}$ Consequently, when the community wishes to do so, it can easily evade responsibility for the verdict it renders through the jury. This flies in the face of the promotion of shared responsibility that the Williams Court identified as a leading purpose of trial by jury.

The function of jury secrecy-especially the absolute secrecy that would bar a court transcription or review of the deliberations-is not unequivocally wedded to the purposes of the criminal jury trial. Moreover, the balance of considerations suggests that the purposes of the jury trial might be better promoted through limited judicial review of deliberations. Accordingly, the Constitution does not prohibit court transcription of jury deliberations.

The constitutional question that transcription presents is whether the presence of a silent, unobtrusive observer (for example, a stenographer, a tape recorder, or a video camera) in the jury room violates the right to a jury trial. Some commentators have suggested that the mere presence of a stranger in the jury room violates a party's right to a jury trial. ${ }^{150}$ Significant precedents suggest that this view is mistaken.

The issue of the silent observer typically arises in the federal courts when an alternate juror is purposely or inadvertently permitted to sit in on jury deliberations. ${ }^{151}$ The Supreme Court has never

143 See Williams, 399 U.S. at 100 (emphasizing "the community participation and shared responsibility" of the jurors in their "determination of guilt or innocence").

${ }^{149}$ The broad-based dissatisfaction with the verdicts in the Simpson case and the Rodney King beating case involved widespread sentiment that these were not "our" verdicts. The "we" in question-the community that renders the verdict through the jury-aspires to be the American society as a whole. The reality, however, at least in the cases cited, appears to be profoundly divided along racial lines. See supra note 120 (citing sources showing racial divide over verdicts in Simpson, Denny, and L.A. police officer trials). There is no reason to think that inspection of deliberations will close this divide. It is, however, morally improper and politically imprudent to purchase the appearance of racial neutrality in the administration of justice by turning a blind eye to the possibility of racism in the jury room.

${ }^{150}$ See Abramovsky, supra note 8 ("[T] would seem at least as likely to 'inhibit or influence the jury by their [very] presence' as the presence of court officers or bailiffs." (second alteration in original with brackets added) (quoting People v. Guzman, 555 N.E.2d 259, 263 (N.Y. 1990))); Note, supra note 5 , at 897 ("Deliberative secrecy ... is of constitutional dimension.").

${ }^{151}$ See United States v. Olano, 507 U.S. 725, 741 (1993) (holding that no plainerror reversal was warranted where alternate jurors were permitted to attend deliberations, but were not permitted to participate, and the defendant failed to show prejudice); Johnson v. Duckworth, 650 F.2d 122, 125 (7th Cir. 1981) (declining to set aside a verdict reached in the presence of an alternate juror); United States v. Virginia 
squarely addressed this issue in constitutional terms, but the Court did consider the issue on plain- and harmless-error grounds in United States $v$. Olano. ${ }^{152}$

In that case, the district court permitted two alternates to attend jury deliberations under instructions not to participate. ${ }^{153}$ Defendants forfeited any claim of error, and the court of appeals therefore reviewed the alleged error under the plain-error standard of Federal Rule of Criminal Procedure 52(b). ${ }^{154}$ The court of appeals reversed the defendants' convictions, finding that the attendance of the alternates constituted plain error, and that the error was "inherently prejudicial." ${ }^{155}$ The Court granted certiorari "to clarify the standard for 'plain error' review... under Rule 52(b)."156 The Court then reversed the Ninth Circuit, ruling that the presence of alternate jurors during deliberations was not inherently prejudicial or reversible per se. ${ }^{157}$

Erection Corp., 335 F.2d 868 (4th Cir. 1964) (vacating judgment entered on a verdict reached in the presence of an alternate juror). The latter two cases are discussed by Professor Abramovsky. See Abramovsky, supra note 8.

${ }^{152} 507$ U.S. at 737. The Court compared the analysis used when an alternate is present to that used in other "intrusion" cases decided by the Court. See id. at 737-39 (discussing several intrusion cases). The Court, while expressly not reaching the constitutional questions, see id. at 739 ('[T]he issue here is whether the alternates' presence sufficed to establish remedial authority under Rule 52(b), not whether it violated the Sixth Amendment or Due Process Clause ...."), made it clear that the Due Process Clause was not violated, see id. at 738 (noting that due process does not require a new trial when a jury is in a potentially compromising position, but merely requires a jury willing to decide the case solely on the evidence and a judge vigilant against prejudicial occurrences (citing Smith v. Phillips, 455 U.S. 209, 217 (1982))), and suggested that there might have been no constitutional violation, see id. at 737 (holding that the presence of alternates is not an error "that 'affect[s] substantial rights' independent of its prejudicial impact" (alteration in original)), though the Court expressly declined to consider whether a constitutional violation might affect substantial rights regardless of prejudice, see id. at 735, 739 (noting that some errors may deprive defendants of basic protection necessary for the functioning of the trial as a fair procedure "regardless of their effects on the outcome," but noting that this question was not presented).

${ }^{153}$ See id. at 729 ("' $[W]$ hat we would like to do in this case is have all of you go back so that even the alternates can be there for the deliberations, but according to the law, the alternates must not participate in the deliberations." (quoting the district court's instructions)).

${ }^{134}$ See id. at 730 ("Because respondents had not objected to the alternates' presence, the court applied a 'plain error' standard under Rule 52(b).").

${ }^{155}$ Id. (citing United States v. Olano, 934 F.2d 1425, 1438 (9th Gir. 1991)).

${ }^{156}$ Id. at 731 .

${ }^{157}$ See id. at 741 ("Because the conceded error in this case did not 'affect substantial rights,' the Court of Appeals had no authority to correct it."). 
The Court decided Olano on the assumption that the alternates' attendance at deliberation constituted plain error. ${ }^{158}$ The Court's analysis turned on whether reversal was warranted under Rule 52(b), not on whether the defendants' Fifth or Sixth Amendment rights were violated. $^{159}$ Consequently, the constitutional question remains open, technically, in the case where the jury's deliberations are transcribed over the defendant's express objection. Nonetheless, in an opinion that more squarely addresses the constitutional question involved, the Seventh Circuit implied that routine transcription of jury deliberations would be constitutionally permissible. ${ }^{160}$

In Johnson v. Duckworth, the Seventh Circuit reviewed the dismissal of a habeas corpus petition by the District Court for the Southern District of Indiana. ${ }^{161}$ The petitioner claimed that the state trial court violated his Sixth and Fourteenth Amendment rights by instructing an "alternate juror to attend, but not participate in, the jury's deliberations." 162 As the petitioner had objected to the alternate juror's attendance, the reviewing court found a constitutional question "of first impression" presented. ${ }^{163}$

On the one hand, the court recognized that "if an intrusion into the jury's privacy has, or is likely to have, the effect of stifling [free] debate, the defendant's right to trial by jury may well have been violated."

${ }^{153}$ See id. at 737 (assuming without deciding, due to a government concession, that Federal Rule of Criminal Procedure 24(c) is nonwaivable, and analyzing deviation from the rule under the plain-error standards of Rule 52(b)).

159 See id. at 739 (noting that the issue was whether the alternates' presence "sufficed to establish remedial authority under Rule 52(b)").

${ }^{160}$ See Johnson v. Duckworth, 650 F.2d 122, 125 (7th Cir. 1981) (noting that "jury privacy is not a constitutional end in itself; it is rather, a means of ensuring the integrity of the jury trial"); cf. Olano, 507 U.S. at 737-38 (suggesting that shielding the jury from improper influence is the primary-and possibly the exclusive-purpose of jury secrecy).

${ }_{162}^{161}$ Johnson, 650 F.2d at 123.

${ }^{165} I d$. at 124 . Obviously, any state procedural irregularity in permitting the alternate to deliberate was not before the federal court on petition for a writ of habeas corpus. See 28 U.S.C. $\S 2254$ (1994) (providing that such petitions may only be entertained on the ground of alleged violations of federal law).

The elimination of this procedural issue serves to distill the problem to its constitutional essence in a way that is not possible when federal jury deliberation is involved. In the federal court, the presence of an alternate will always involve a deviation from Rule 24(c); therefore, there will always be a procedural ground of error, eliminating the need to reach a question of constitutional error.

${ }^{164}$ Johnson, 650 F.2d at 125. 
privacy is not a constitutional end in itself; it is, rather, a means of ensuring the integrity of the jury trial. ${ }^{165}$ In fact, the court noted that sometimes "jury privacy must be breached in the name of protecting the defendant's right to a jury trial. ${ }^{166}$ The court then reasoned that the proper approach to the constitutional question presented was to determine whether the alternate's presence is "the sort of invasion of the jury's privacy that will tend to stifle the jury's debate, thus endangering the defendant's right to trial by jury."

In carrying out its analysis, the Johnson court not only looked to whether the intrusion was likely to stifle free debate among the jurors, but also weighed the state's purpose in breaching jury secrecy. ${ }^{168}$ In doing so, the court followed the lead of the Supreme Court's decision in Ballew v. Georgia. ${ }^{169}$

In Ballew, the Court posed the question of whether a state criminal jury of fewer than six persons "inhibits the functioning of the jury as an institution to a significant degree, and, if so, whether any state interest counterbalances and justifies the disruption so as to preserve its constitutionality." criminal jury is impaired to a constitutional degree by a reduction in size below six. ${ }^{171}$ The Court further found that Georgia "offered little or no justification for its reduction [of the jury] to five members"172 and reversed the conviction. ${ }^{173}$

No court has addressed the precise question regarding the constitutionality of permitting transcription of jury deliberations. The cases discussed above, however, establish the principles necessary to resolve the question. First, criminal defendants' rights under the Sixth and Fourteenth Amendments can be counterbalanced by significant

$165 I d$.

${ }^{166} I d$. For instance, the court suggested that breaching jury secrecy would be appropriate to determine "whether a juror's vote was predicated upon a bribe rather than upon a conscientious evaluation of the evidence." Id. (citing Clark v. United States, 289 U.S. 1, 14 (1933)).

${ }^{167}$ Id. at 125.

${ }^{163}$ See id. at 126 ("Of additional significance is the state's purpose in requiring the alternate to be a silent observer of the jury's deliberations.").

${ }^{169}$ See id. at 126 n.8 (citing Ballew v. Georgia, 435 U.S. 223, 243-44 (1978)):

170 U.S. at 231.

${ }^{171}$ See id. at 239 ("Because of the fundamental importance of the jury trial ..., any. further reduction that promotes inaccurate and possibly biased decisionmaking, that causes untoward differences in verdicts, and that prevents juries from truly representing their communities, attains constitutional significance.").

172 Id. at 244.

${ }^{173}$ See id. at 245. 
government interests. Second, jury secrecy is not a constitutional end in itself, but can be breached to secure the rights of criminal defendants. This means that one can uphold the constitutionality of routine recording of jury deliberations for judicial review-even over a criminal defendant's objection-in conformity with Supreme Court precedent like Ballew, as interpreted by Johnson, and consistent with the weight of federal-court opinion in the related area of Rule 24(c) violations of jury secrecy. ${ }^{174}$

Arguably, judicial review of jury deliberations furthers the fairtrial rights of criminal defendants as a class. Even if one assumes that court-recording is the "sort of invasion of the jury's privacy that will tend to stifle the jury's debate," ${ }^{175}$ such review can provide a valuable check on improper jury deliberations that are as dangerous to the defendant's rights as is restricted debate. ${ }^{176}$ For instance, if deliberations were reviewable, convictions based on consideration of matters not in evidence or on impermissible bias against the defendant could more readily be overturned. ${ }^{177}$ Moreover, even if one thinks that court recording of jury deliberations intrudes on the criminal defendant's rights, one can argue that the important governmental interests fostered by open proceedings (legitimacy, prevention of fraud, and community therapeutic value) outweigh whatever infringement the practice may involve.

\section{Civil Trials}

The Seventh Amendment to the Constitution provides that:

In suits at common law, where the value in controversy shall exceed twenty dollars, the right of trial by jury shall be preserved, and no fact tried by a jury, shall be otherwise re-examined in any court of the United States, than according to the rules of the common law. ${ }^{178}$

174 See United States v. Olano, 507 U.S. 725, 738-39 (1993) (noting that intrusions on the jury are generally to be analyzed for prejudicial impact rather than for constitutional violation).

${ }^{175}$ Johnson, 650 F.2d at 125.

${ }^{176}$ See Abramovsky, supra note 8 (recognizing that valid arguments can be made for recording the jury as a routine procedure). But see $i d$. at 40 (concluding that "[a]ny good that would come from routine taping of jury deliberations ... would be heavily outweighed by the harm that would be done to the impartiality of juries").

${ }^{77}$ Of course, the Double Jeopardy Clause protects the defendant against use of the jury transcript against him after a not-guilty verdict. See U.S. CONST. amend. V (" $[N]$ or shall any person be subject for the same offence to be twice put in jeopardy of life or limb....").

${ }^{178}$ Id. amend. VII. 
Unlike the Sixth Amendment, however, the Seventh Amendment is not incorporated into the Fourteenth Amendment: "[T]he Seventh Amendment applies only to proceedings in courts of the United States and does not in any manner whatever govern or regulate trials by jury in state courts or the standards which must be applied concerning the same."

This fact of nonincorporation is less important than it may first appear. First, we are considering the recording of jury deliberations in federal courts, where the Seventh Amendment expressly applies. Second, almost all state constitutions "have civil jury trial provisions roughly analogous in form and substance to the seventh amendment." It is is likely that state courts look to federal Seventh Amendment jurisprudence in interpreting those provisions. ${ }^{181}$ If state courts interpret state constitutional provisions in accordance with federalcourt interpretations of substantially identical federal constitutional provisions, the result for those states would seem to be the practical equivalent of the incorporation of the federal provision into the

${ }^{179}$ Minneapolis \& St. Louis R.R. Co. v. Bombolis, 241 U.S. 211, 217 (1916); see also Colgrove v. Battin, 413 U.S. 149, 169 n.4 (1973) (Marshall, J., dissenting) ("[T]he Seventh Amendment is one of the few remaining provisions in the Bill of Rights which has not been held to be applicable to the States."); Hardware Dealers Mut. Fire Ins. Co. v. Glidden Co., 284 U.S. 151, 158 (1931) ("The Fourteenth Amendment neither implies that all trials must be by jury, nor guarantees any particular form or method of state procedure."); Wagner Elec. Mfg. Co. v. Lyndon, 262 U.S. 226, 232 (1923) (“[T]he deprivation of a right of trial by jury in a state court does not deny the parties due process of law under the Federal Constitution."); Walker v. Sauvinet, 92 U.S. 90, 92 (1875) ("The States, so far as [the Seventh Amendment] is concerned, are left to regulate trials in their own courts in their own ways. A trial by jury in suits at common law pending in the State courts is not, therefore, a privilege or immunity of national citizenship, which the States are forbidden by the Fourteenth Amendment to abridge.").

${ }^{180}$ Paul B. Weiss, Comment, Reforming Tort Reform: Is There Substance to the Seventh Amendment?, 38 CATH. U. L. REV. 737, 739 (1989); see also id. at 739 n.11 (noting such provisions in the constitutions of every state except for Colorado and Louisiana).

${ }^{181}$ See id. at $739 \mathrm{n} .12$ (stating that Seventh Amendment jurisprudence may constitute persuasive authority in state courts). For instance, state courts have looked to Supreme Court interpretations of the Seventh Amendment in holding that remittitur does not violate state constitutional rights to a civil jury trial. See, e.g., Lisle v. Willis, 463 S.E.2d 108, 110 (Ga. 1995) (following Arkansas Valley Land \& Cattle Co. v. Mann, 130 U.S. 69 (1889)). Indeed, some state courts have even followed the more controversial federal additur jurisprudence. See Bressler v. Mull's Grocery Mart, 461 S.E.2d 124,128 (W. Va. 1995) (holding that additur violates a state civil-jury constitutional provision except in narrow circumstances (citing Dimick v. Schiedt, 293 U.S. 474, 486 (1935))); cf. Carney v. Preston, 683 A.2d 47, 50 (Del. Super. Ct. 1996) (stating that the Supreme Court's controversial Dimick decision cannot simply be ignored in a statecourt additur case, even though the state constitution in fact permits additur). 
Fourteenth Amendment. Consequently, a review of the Supreme Court's interpretations of the Seventh Amendment is appropriate for deciding the constitutionality of recording jury deliberations. ${ }^{182}$

Aside from the difference on incorporation, Seventh Amendment jurisprudence is quite similar to Sixth Amendment jurisprudence. ${ }^{189}$ The Seventh Amendment "does not "bind the federal courts to the exact procedural incidents or details of jury trial according to the common law in 1791,' and '[n] ew devices may be used to adapt the ancient institution to present needs and to make of it an efficient instrument in the administration of justice." ${ }^{184}$ The analysis of a particular procedure with respect to the jury is functional, just as it is in the Sixth Amendment context.

Just as the Williams Court analyzed the function of jury size in relation to the essential purposes of the criminal jury, ${ }^{185}$ so the Court in Colgrove stated:

Our inquiry turns, then, to whether a jury of 12 is of the substance of the common-law right of trial by jury. Keeping in mind the purpose of the jury trial in criminal cases to prevent government oppression, and, in criminal and civil cases, to assure a fair and equitable resolution of factual issues, the question comes down to whether jury performance is a function of jury size. ${ }^{180}$

The Court expressly stated that the sole purpose of the civil jury is completely included as one of the two purposes of the criminal jury. Consequently, the Seventh Amendment purpose/function analysis of court recording of jury deliberations should track the Sixth Amendment analysis. The Sixth Amendment analysis established that court recording of jury deliberations promotes the purpose of fairness (for example, by making the jury less likely to decide cases on matters not in evidence or to bring impermissible bias to bear on their deci-

${ }^{182}$ Cf. Weiss, supra note 180 , at 739 (noting that "state jury trial provisions are ... amenable to seventh amendment analysis").

${ }^{183}$ See Colgrove, 413 U.S. at 151-52 (holding that the additional references to the "common law" contained in the Seventh Amendment do not support a different interpretation of the jury-trial right in civil as opposed to criminal cases, as regards the number of constitutionally required jurors (following Williams v. Florida, 399 U.S. 78, 86 (1970) (holding six-member juries in state criminal trials constitutionally permissible))).

${ }^{184} I d$. at $156-57$ (alteration in original) (citations omitted) (quoting Galloway v. United States, 319 U.S. 372, 390 (1943), and Ex parte Peterson, 253 U.S. 300, 309-10 (1920)).

${ }^{185}$ See Williams, 399 U.S. at $99-100$ ("The relevant inquiry... must be the function that the particular feature performs and its relation to the purposes of the jury trial.").

${ }^{185}$ Colgrove, 413 U.S. at 157 (citations omitted). 
sions). ${ }^{187}$ Insofar as this applies equally in the Seventh Amendment context, the purpose/function analysis of transcription of civil-jury deliberations is constitutionally permissible.

Of course, the Seventh Amendment does differ from the Sixth Amendment in providing that no fact decided by a jury shall be reexamined in a federal court otherwise "than according to the rules of the common law. ${ }^{188}$ Nonetheless, the common law provides numerous devices for taking cases away from the jury and restricting or reviewing the jury's factfinding; ${ }^{189}$ these devices do not offend the Seventh Amendment. ${ }^{190}$ Recording the jury's deliberations, then, does not involve any new kind of reexamination of fact that would violate the Seventh Amendment. Rather, the procedure simply permits the court to review the jury's fact-finding according to the best evidence, namely an actual transcript of the jury's deliberation.

\section{B. Statutes and Rules}

Section 1508 of the federal criminal code bars recording of the deliberations or voting of grand or petit juries; the statute also bars nonjurors from listening to or observing such proceedings. ${ }^{191}$ The statute does not prohibit a juror from taking notes for the purpose of assisting her to perform her duties as a juror. ${ }^{192}$ If courts are to begin to experiment with the recording of jury deliberations, without opening the floodgates to other types of court-authorized recording of juries (such as television broadcast or observation by researchers), the statute must be amended. A paragraph similar to the following should be added to the statute:

${ }^{187}$ See supra Part IV.A.1.

${ }^{283}$ U.S. CONST. amend. VII.

${ }^{189}$ See JAMES ET AL., supra note 106, $\$ 7.8$ (discussing, inter alia, new trial, j.n.o.v., directed verdict, and special verdict). Both the new trial and the j.n.o.v. rest, in some degree, on the reexamination of facts found.

${ }_{190}$ See id. $\$ 7.24$, at 382 ("Granting new trials for judicial errors, juror misconduct, a verdict that is excessive or against the weight of the evidence, and 'all sorts of errors and mistakes on the part of the jury' had become fairly well established at common law by the late eighteenth century. This procedure, therefore, is regarded as consistent with the federal and typical state constitutional provisions guaranteeing jury trial." (footnote omitted) (quoting E.W. Hinton, Power of Federal Appellate Court to Review Ruling on Motion for New Trial, 1 U. CHI. L. REV. 111, 112 (1933))).

${ }^{191}$ See 18 U.S.C. \$ 1508 (1994).

${ }^{192}$ See id. ("Nothing .... shall be construed to prohibit the taking of notes by a grand or petit juror ... for the purpose of assisting [her] in the performance of his duties...."). 
Nothing in this section shall be construed to prohibit judges or justices in the courts of the United States from authorizing recording of petit jury deliberations for the purpose of judicial review. Nor shall this section be construed to prohibit a court or a party to a proceeding in which a petit jury's deliberations have been recorded from reviewing the record of that jury's proceedings, if the court permits.

Such an amendment of the statute not only makes possible the recording in the first instance, it also protects the parties from liability for reviewing the transcript, which arguably would be criminal under the current statute's prohibition of nonjuror observation of deliberations. By the same token, the amendment acknowledges that the parties' access to the transcript depends on the leave of the court. The court thus retains discretion to seal the transcript in the interest of justice-for instance, from those who seek the transcript to harass or retaliate against jurors. ${ }^{193}$

Federal Rule of Evidence 606(b) prohibits a juror's testimony from being used to impeach the jury's verdict. ${ }^{194}$ This Comment has already examined the purpose of the rule and has suggested that the proposal to record the jury's deliberations may violate the letter, but not the spirit, of the rule. ${ }^{195}$ Accordingly, the rule should be amended as follows:

Nothing in this rule prohibits any court of the United States, or the parties to an action with the permission of the trial court, from using a transcript of jury deliberations for the purpose of judicial review. The trial court may review the transcript or may seal the transcript, as the interest of justice requires.

An important feature of such an amendment is that it leaves discretion with the trial court over the decision whether to give the parties access to the transcript. The amendment also gives any federal court the authority to use the transcript for the purposes of judicial review; certainly an appellate court reviewing a trial court's ruling on a deliberation transcript should have the same access to the transcript that the trial court had.

193 The proposed amendment to title 18 simply acknowledges the courts' authority to seal the transcript; it should not be construed to imply an automatic limit on review of the transcript. If Congress wishes to regulate the procedural use of the transcript, such legislation clearly would belong in title 28 .

194 FED R. Evid. 606(b).

195 See supra Part II.A.2. 


\section{NATURE AND SCOPE OF JUDICIAL REVIEW OF COURT-RECORDED JURY DELIBERATIONS}

Two common criticisms of juries are that they often fail to decide cases on the evidence (whether out of prejudice or incompetence) ${ }^{196}$ and that they often fail to follow the law (out of ignorance or willfulness) ${ }^{197}$ To some extent, the law provides a corrective mechanism for these problems, through the motion for new trial. ${ }^{198}$ The trial court's power to grant a new trial is broad: "It embraces all the reasons which inhere in the integrity of the jury system itself," 199 and the judge "should not hesitate to set aside [the jury's] verdict and grant a new trial in any case where the ends of justice so require. ${ }^{200}$ The exercise of the power does not violate the Seventh Amendment, "but is one of the historic safeguards of that right." ${ }^{201}$

The policy of jury secrecy, however, especially in the civil context, severely restricts the effectiveness of the new-trial motion:

A common ground for a motion for a new trial is that the jury, or members of it, has not performed in the fashion expected of juries. Attacks on this ground are frequently abortive because... the circumstances under which the jurors themselves may testify to impeach the verdict are very limited. ${ }^{202}$

196 See, e.g., Hearings, supra note 13, at 73-74 (memorandum submitted by Harry Kalven, Jr.) (noting arguments that jurors are bad factfinders because they are not expert in the weighing of evidence and because parties appeal to jurors' prejudices); Marcus A. Brown, Commentary: Trial by Jury-An Obsolete Concept, 49 CoNSUMER FIN. L.Q. REP. 109, 109 (1995) (" $\mathrm{J}]$ urors may be swayed by appeals made to prejudice or emotion and may be unable to evaluate the evidence placed before them.").

197 See, e.g., Hearings, supra note 13, at 73-74 (memorandum submitted by Harry Kalven, Jr.) (noting arguments that jurors are unable to understand the law and unable to follow the court's instructions); Brown, supra note 196, at 109 ("Juries often do not follow the law, either because they misunderstood the judge's instructions or do not like a particular law.").

198 See generally 11 Charles ALAN Wright ET AL., Federal PRACTICE AND PROCEDURE $\$ \$$ 2801-2810 (2d ed. 1995) [hereinafter WRIGHT \& MILLER] (discussing newtrial motion and grounds for a new trial).

${ }^{199}$ Tidewater Oil Co. v. Waller, 302 F.2d 638, 643 (10th Cir. 1962), quoted in WRIGHT \& MILLER, supra note 198, §2801, at 40.

${ }^{200}$ Aetna Casualty \& Surety Co. v. Yeatts, 122 F.2d 350, 354 (4th Cir. 1941), quoted in WRIGHT \& MILLER, supra note 198, \$2801, at 41 .

${ }^{201}$ Yeatts, 122 F.2d at 353, quoted in WRIGHT \& MILLER, supra note 198, § 2801, at 40.

${ }^{202}$ WRIGHT \& MILLER, supra note 198, $\$ 2810$, at 105; see also 12 JAMES W. MOORE ET AL., MOORE'S FEDERAL PRACTICE \$ 59.23[3], at 59-40 (3d ed. 1997) (noting that a motion for new trial on the ground that the verdict resulted from an improper motive "will be difficult to support due to the common law rule prohibiting a juror from impeaching the verdict"). 
The question to be examined in this Part is how the recording of jury deliberations should operate to correct verdicts rendered contrary to the evidence or to the law. Two central points are to be established. First, transcribing of jury deliberations does not establish a new remedy; it merely rests an established remedy (the new trial) on a surer evidentiary foundation. Second, transcribing jury deliberations will not seriously infringe on the interest of judicial economy, which has always been and remains adequately protected in the new-trial context by the harmless-error doctrine. ${ }^{203}$ These two points hold true regardless of whether the verdict is challenged as contrary to the evidence or contrary to the law.

\section{A. Verdicts Contrary to the Evidence}

On a motion for new trial, the verdict loser may attack either the weight of the evidence or the legal sufficiency of the evidence. ${ }^{204}$ The judge must ensure that "the verdict is consistent with the evidence," but the judge must defer to the jury on matters within its province, and "a new trial is warranted only if the verdict is so clearly against the weight of the evidence as to amount to a manifest miscarriage of justice." ${ }^{205}$ Accordingly, while the grant or denial of the motion is committed to the sound discretion of the trial judge, reviewing courts

${ }^{209}$ For simplicity of analysis, this Part will focus on federal practice and procedure in civil trials.

${ }^{204}$ See MOORE ET AL., supra note 202, § 59.25[1], at 59-46 (discussing verdict against the weight of the evidence as ground for new trial and noting that new trial on this ground can be awarded when evidence was legally insufficient but Rule 50(b) "j.n.o.v." is unavailable (for instance, because the motion for j.n.o.v. is untimely made)).

Transcripts of jury deliberations would clearly be helpful on a weight-of-theevidence new-trial motion. In principle, a motion for j.n.o.v., or a new-trial motion, based on the legal sufficiency of the evidence, should not be affected by the contents of such a transcript. In practice, of course, it is possible that a judge inclined to grant a j.n.o.v. without a transcript could discover in the transcript a rational basis for the verdict that otherwise would have eluded her. In other words, it is possible that a transcript of jury deliberations could prevent a judge from wrongly entering a j.n.o.v.

Of course, other grounds for a new trial exist that involve the evidence: the size of the verdict, see WRIGHT \& MILLER, supra note $198, \S 2807$, and newly discovered evidence, see $i d$. $\S 2808$. The former properly can be subsumed under the discussion of the weight-of-the-evidence motion. Both grounds allege that the evidence does not warrant the verdict; the difference between the motions is merely in the element of proof on which the evidence is alleged to be scant.

${ }^{205}$ MOORE ET AL., supra note 202, § 59.25[1], at 59-46. 
will inspect grants of the motion in the weight-of-the-evidence context more closely than in other contexts. ${ }^{206}$

Taking these principles together, the weight-of-the-evidence motion for new trial seems to be a "jury-rigged" solution to the problem of the inadmissibility of juror testimony to impeach a verdict. The motion is brought where the evidence in favor of the verdict is legally sufficient, yet the verdict does not comport with the judge's assessment of the weight of the evidence. ${ }^{207}$ We indulge the fiction that the trial judge, in granting the motion, does not substitute her judgment for that of the jury but acts only to prevent a miscarriage of justice. But the suspected miscarriage of justice is thought to have transpired in the jury room; that is, something caused the jury to decide the case contrary to what justice demands. Without a record of the jury's deliberations, however, the suspicion of miscarriage is entirely speculative. It would be far better simply to examine what the jury in fact did in the room. We then could arrive at a reliable determination of whether the jury decided the case on the legally sufficient evidence or instead perpetrated a miscarriage of justice. As it stands now, the motion is made and granted on the least desirable of grounds: speculation as to why the jury decided as it did.

With a transcript of the jury's deliberation, the trial court can determine whether the jury in fact decided the case on improper grounds. If it did, the movant deserves a new trial, since she has an important right to have her cause decided only on the properly admitted evidence and the relevant law. ${ }^{208}$ Concerns of judicial economy that properly figure in the common-law doctrines of new trial, however, should be retained. Consequently, the movant should bear a heavy burden of proof to rebut the presumption that a verdict on legally sufficient evidence is properly rendered. By and large, the harmless-error rule ${ }^{209}$ will give concerns of judicial economy all the protection they require.

${ }^{206}$ See id. $\$ 59.25$ [2], at $59-47$ to -48 (discussing stringency of appellate review of trial court's grant of a new trial).

${ }^{207}$ See id. $\$ 59.25[1]$, at $59-46$ (noting that a new trial can be granted even when evidence is legally sufficient to deny the ultimate verdict loser judgment as a matter of law).

${ }^{208}$ See id. $\$ 59.23$ [3], at 59-40 (stating that a new trial should be granted when the verdict is the result of "mistake, passion, prejudice, compromise, or improper motive" on the jury's part, or where it is coerced by the court).

${ }^{209}$ See FED. R. CIV. P. 61 ("The court at every stage of the proceeding must disregard any error or defect in the proceeding which does not affect the substantial rights 
Consider, then, the chronic complaint about juries: that they decide cases on matters not in evidence. The jury's mere consideration of matters not in evidence should not result automatically in a new trial in every case. ${ }^{210}$ The movant should first overcome the harmlesserror rule with a clear and convincing showing of prejudice in fact. Nonetheless, on such a showing, the verdict should be set aside in order to vindicate the movant's right to a fair trial.

\section{B. Verdicts Contrary to the Law}

The verdict loser has a difficult time winning a new trial on the ground that the jury's verdict was against the weight of the evidence. ${ }^{211}$ Yet the situation is arguably more dire where the interest in granting the new trial is even greater, namely, in cases where there is ground to believe that the verdict resulted from jury misconduct or

of the parties."). For a comprehensive discussion of the harmless-error doctrine, see WRIGHT \& MILLER, supra note 198, $\$ \S 2881-2883$.

Assuming that the transcript reveals improper conduct by the jury, there are of course two possible assignments of error: court error in denying a new trial on the grounds of the jury's conduct, or jury error in the conduct itself. The harmless-error rules are silent on the issue of jury error, but such an error, like the errors specifically mentioned in the rules, should be subject to the rule. Thus, an amendment of Federal Rule of Civil Procedure 61 to include error by the jury is proper. Because the language of the criminal harmless-error rule is broader, see FED. R. CRIM. P. 52(a) ("Any error ... which does not affect substantial rights shall be disregarded."), it needs no amendment.

The phenomenon of jury nullification raises policy questions that are beyond the scope of this Comment. Therefore, it is merely noted that recording jury deliberations would provide evidentiary support for reversal of a nullification verdict. Whether or not such reversal is proper is not within the scope of this Comment.

${ }^{210}$ Indeed, there is good reason to presume that juries often discuss improper considerations, but this does not imply that they deliberate poorly:

[J]uries ... often discuss matters the judge told them to ignore or which were not mentioned in the trial .... [I]rrelevant factors, including litigant personalities and social status, are most likely to intrude when the evidence is unclear....

Considering our knowledge of group decision-making-from formal studies of it, as well as the common experience of those who participate in such activities-it would be utterly amazing to hear that irrelevancies did not sometimes creep into jury deliberations. What is impressive, based on a consensus view of the research, is how little of it occurs.

JOHN GUINTHER, THE JURY IN AMERICA 88 (1988) (footnote omitted).

${ }^{811}$ See MOORE ET AL., supra note $202, \S 59.25$ [1]-[2], at $59-46$ to -48 (noting that new trial should only be granted based on a miscarriage of justice and noting that the standard of appellate review of rulings on the motion leans heavily in favor of upholding the jury's verdict). 
confusion. ${ }^{212}$ Again, the law's restriction of the availability of the best evidence appears to impair the parties' fair-trial rights. ${ }^{213}$ Moreover, the admission of that best evidence would not be so costly to judicial economy to justify its continued exclusion.

Consider the other chronic complaint about juries: that they ignore or misunderstand the relevant law when they decide a case. One might endeavor to improve jury instructions, increasing the jury's understanding of the relevant law. But a more direct approach-observing the jury's deliberations to see whether it in fact understood the law-is preferable. In fact, the two remedies are not exclusive; but only the latter attempts to remedy juror misconstrual of the law after it inevitably occurs.

Considerations of judicial economy require that a movant clearly show more than that the jury merely was confused about the governing law or did not share the same understanding of it that the court did. By the same token, a movant has a right to a new trial where the record clearly and convincingly reveals that the jury's construal of the relevant law was erroneous and the error was material to the outcome-that is, that the error prejudiced the movant in fact. But, again, this is precisely the type of standard that would govern if the record of jury deliberations were admissible for review under a harmless-error standard.

In short, recording of jury deliberations will not involve the development of much new law of post-verdict review. Rather the practice will primarily serve to place review on the firm foundation of the best available evidence. Considerations of judicial economy, currently protected with the ill-suited instrument of jury secrecy, will not be sacrificed by recording deliberations. The harmless-error rule will continue to give these considerations their due, but in an atmosphere of less legal fiction and more substantial justice.

${ }^{212}$ See MOORE ET AL., supra note 202, § 59.23[3] (noting improper jury motivation as ground for new trial and referring to "mistake, passion, prejudice, compromise, or other improper motive"); WRIGHT \& MILLER, supra note 198, § 2810 (noting misconduct affecting the jury as ground for new trial and referring to compromise, quotient verdict, inconsistency, and failure to follow the court's instructions).

${ }^{213}$ See MOORE ET AL., supra note 202, § 59.23 [3], at 59-40 (noting that the commonlaw jury-impeachment rule renders a new-trial motion based on improper motive "difficult to support"); WRIGHT \& MILLER, supra note $198, \S 2810$, at 105 (noting that the common-law rule barring juries from impeaching their verdict frequently renders ineffective a new-trial motion based on misconduct affecting the jury). 


\section{CONCLUSION}

The institution of the jury, like all our governmental institutions, demands a balance between the competing virtues of public accountability and pragmatic tolerance of imperfection. The tradition of jury secrecy has for too long sacrificed the former to the latter. As the demand for public accountability of the institution increases, more and more public inquiries (especially media inquiries) into jury deliberations appear. One does well to acknowledge the legitimacy of the impulse toward inspection of the jury's conduct, even if one opposes general publication of the contents of jury deliberations. The public interest in accountability of the jury should be met by giving the courts, rather than the press, access to the jury's deliberations, for the purpose of limited judicial review. Transcribing jury deliberations for judicial review offends two acts of Congress, which should be amended, but the practice does not offend the Constitution. Such transcription will enhance the legitimacy, rationality, and fairness of jury trials, without unduly infringing on the dignity or economy of judicial proceedings. 
$* * * * * *$ 